\title{
A checklist of endemic plants on the Korean Peninsula
}

\author{
Gyu Young Chung*, Kae Sun Chang', Jae-Min Chung ${ }^{2}$, Hyeok Jae Choi', \\ Weon-Ki Paik ${ }^{4}$ and Jin-Oh Hyun ${ }^{5}$
}

\author{
Department of Medicinal Plant Resources, Andong National University, Andong 36729, Korea \\ ${ }^{1}$ Forest Biodiversity Division and Herbarium, Korea National Arboretum, Pocheon 11186, Korea \\ ${ }^{2}$ Conservation Division, Korea National Arboretum, Pocheon 11186, Korea \\ ${ }^{3}$ Department of Biology and Chemistry, Changwon National University, Changwon 51140, Korea \\ ${ }^{4}$ Division of Life Science and Chemistry, Daejin University, Pocheon 11159, Korea \\ ${ }^{5}$ Northeastern Asia Biodiversity Institute, Seoul 05677, Korea \\ (Received 5 September 2017; Revised 13 September 2017; Accepted 22 September 2017)

\section{한반도 특산식물 목록} \\ 정규영* ${ }^{*}$ 장계선 ${ }^{1} \cdot$ 정재민 $^{2} \cdot$ 최혁재 $^{3} \cdot$ 백원기 $^{4} \cdot$ 현진오 $^{5}$ \\ 안동대학교 생약자원학과, ${ }^{1}$ 국립수목원 산림생물조사과, \\ 2국립수목원 산림자원보존과, ${ }^{3}$ 창원대학교 생물학화학융합학부, \\ ${ }^{4}$ 대진대학교 생명화학부, ${ }^{5}$ 동북아생물다양성연구소
}

\begin{abstract}
In order to organize a new checklist for endemic vascular plants of the Korean Peninsula, 358 taxa of the Korea Forest Service and 375 taxa of the National Institute of Biological Resources were reviewed. In addition, the names of previously published endemic plants above the rank of variety were checked up to 2016. From the two lists, a total of 444 taxa were identified. Among them, 289 taxa were common on the two lists, but 69 and 86 taxa were listed only by the Korea Forest Service and by the National Institute of Biological Resources, respectively. Taxonomic documents including journal papers and dissertations were examined with regard to the 444 taxa. In some cases, opinions of Korean experts in this field were also reflected. From the results, 312 taxa in total were recognized as plants endemic to the Korean Peninsula, while 132 taxa could not be included on the endemic list. On the other hand, 48 taxa, none of which existed on the two lists, were newly listed. In conclusion, the new checklist of vascular plants endemic to Korea was confirmed, with a total of 360 taxa consisting of 64 families, 172 genera, 297 species, 4 subspecies, 51 varieties and 8 hybrids. The new common name Halla-seol-aeng-cho is given to Primula farinosa L. subsp. modesta (Bisset \& S. Moore) Pax var. hannasanensis (T. Yamaz.) T. Yamaz. Sillaphyton Pimenov (Deok-u-gireum-na-mul-sok) is newly identified as a genus endemic to Korea. However, Pentactina Nakai could not be included on the list of Korean vascular endemic genera.
\end{abstract}

Keywords: Endemic, vascular plants, Korean Peninsula, checklist

적 요: 한반도의 특산 관속식물 목록을 새롭게 정리하기 위하여 Korea Forest Service의 358 분류군과 National Institute of Biological Resources의 375분류군의 목록을 재검토하였다. 추가로 2016년까지 변종 이상 의 새로운 특산분류군으로 발표된 학명들을 포함하여 목록을 정리하였다. 두 목록을 비교한 결과, 공통분류 군은 289분류군, Korea Forest Service 단독 취급 분류군은 69분류군, National Institute of Biological Resources 단독 취급 분류군은 86 분류군으로 이들은 총 444 분류군으로 취합되었다. 이들 444 분류군들에 대

\footnotetext{
*Author for correspondence: gychung@andong.ac.kr
} 
하여 국내 학위 논문을 포함한 학술자료 및 필요에 따라 국내 전문가들의 의견을 검토한 결과, 한반도 특산 으로 인정되는 312 분류군 그리고 제외되는 132 분류군으로 정리되었다. 추가로 두 목록들에는 언급되지 않았 으나 2016년까지 발표된 자료들을 통하여 새로이 48분류군이 특산으로 인정되어 최종적으로 64 과 172속 297종 4아종 51변종 8잡종의 총 360분류군을 한반도 특산으로 정리하였다. Primula farinosa L. subsp. modesta (Bisset \& S. Moore) Pax var. hannasanensis (T. Yamaz.) T. Yamaz.는 한라설앵초로 국명을 신칭하였 다. 덕우기름나물속(Sillaphyton Pimenov)이 새롭게 한반도 특산속으로 추가되었으며, 그 동안 한반도 특산속 으로 취급되어온 금강인가목속(Pentactina Nakai)은 특산속에서 제외되었다.

주요어: 특산, 관속식물, 한반도, 목록

특산식물(또는 고유식물; endemic plants)이란 어느 한정 된 지역에서만 생육하는 식물을 말하며(Anderson, 1994; Williams et al., 2002; Siljak-Yakovlev and Peruzzi 2012), 이때 한정된 지역이란 일반적으로 국가 단위로 적용하고 있는 실정이다. 최근 국제적으로 생물다양성협약(Convention on Biological Diversity, CBD)과 유전자원에 대한 접근과 이 용에 따른 이익의 공정하고 공평한 공유에 관한 나고야의 정서의 발효에 따라 각국이 생물주권을 강화하고 있는 현 실에서, 한반도 특산식물이 우리나라의 생물주권에서 최 우선적으로 고려되어야 할 대상임은 분명하다(Paik, 1999; Oh et al., 2005; Kim et al., 2009).

한반도의 특산 관속식물은 Nakai (1952)가 1,118분류군 을 처음으로 정리한 이후, 현재까지 품종을 제외하면 Lee (1984)가 387분류군, Paik (1999)이 465분류군, Kim (2004) 이 340 분류군, Oh et al. (2005)이 326 분류군, Korea Forest Service (KFS) (2012)가 358분류군, National Institute of Biological Resources (NIBR) (2013)가 375분류군, 그리고 Park et al. (2013a)이 59분류군으로 정리하는 등 새로이 한 반도 특산으로 발표되는 분류군들의 수를 감안하더라도 아직까지 학명 및 분류학적 실체에 대한 이견으로 인해 많은 혼란이 야기되고 있음은 분명하다(Kim et al., 2009).

최근 들어 국내에서 특산으로 간주되던 분류군 중 일부 가 러시아, 중국, 일본 등 주변국의 관련 연구에서 새롭게 분포사실이 밝혀지거나 근연 분류군의 이명으로 처리되 는 경우가 빈번하다. 그러나 이에 대한 국내학자들 중심 의 재검토는 잘 이루어지지 않고 있어 한반도 특산식물들 의 실체에 대한 혼란이 가중되고 있다. 그러므로 특산식 물에 대한 최근의 연구경향을 반영한 새로운 목록의 제시 는 무엇보다도 중요하고 또한 시급한 분류학계의 현안으 로 대두되고 있으며, 이는 특산식물에 대한 국가적 주권 주장에 일조할 것이다.

\section{재료 및 방법}

본 재검토는 한반도 특산 관속식물과 관련하여 비교적 최근에 국가적 차원에서 제시된 KFS (2012)의 358분류군 과 NIBR (2013)의 375분류군의 목록을 중심으로 수행되 었다. 아울러 2016년까지 한반도 특산으로 새로이 발표된
모든 학명들을 대상으로 관련 학술지, 학위논문 및 도감 등의 자료들을 검토하였다. 한반도 특산식물의 선정 기준 은 다음과 같다. 첫째, 분포지 관점으로 (1) 한국 특산식물 은 지구상에서 한반도에만 분포하는 식물로 정의하고, (2) 한국 특산식물로 알려진 분류군에 대하여 중국, 러시아 또는 일본 등의 국외에 분포하는 사실이 학술지 등을 통 하여 발표된 객관적인 자료가 있는 경우 해당 분류군에 대한 국내 전문가를 통한 검토과정을 거쳐 특산에서 제외 하였다. 둘째, 분류군의 실체 관점으로 국내외 학자가 한 반도산 표본을 인용하여 공식적으로 변종이상의 다른 분 류군의 이명으로 분류학적 처리를 한 경우 특산식물에서 제외하였으며, 단 표본 등의 근거자료 없이 식물지 등에 서 단순히 이명으로 언급된 경우 국내 전문가가 동의하지 않으면 특산으로 처리하였다. 셋째, 분류계급 관점으로 현재 품종으로 취급되는 분류군은 특산식물에서 제외하 였으며, 교잡종은 포함하였다. 넷째, 명명규약 관점에서 비합법명(invalid name) 및 서명(illegitimate name)은 실체 에 관계없이 특산식물에서 제외하였다.

이상의 기준들을 통하여 한반도 특산식물 목록을 양치 식물, 나자식물, 피자식물의 쌍자엽식물과 단자엽식물 순 으로 구성하고, 과명과 학명의 알파벳순으로 정리하였다 (Appendix 1). 아울러 기존에 KFS (2012) 또는 NIBR (2013) 에는 언급되었으나 본 재검토를 통해 특산에서 제외되는 분류군들은 그 사유와 함께 Appendix 2에 제시하였다.

\section{결 과}

주 검토 대상인 KFS (2012)와 NIBR (2013)의 목록을 비 교한 결과, 두 목록에서 공통적으로 한반도 특산으로 인 정하는 분류군은 289분류군, KFS (2012)에서만 인정하는 분류군은 69분류군, 그리고 NIBR (2013)에서만 인정하는 분류군은 86 분류군으로 확인되었고, 이들은 종합하면 총 444 분류군으로 정리되었다(Table 1). 이들 총 444분류군들 에 대한 관련 학술자료 및 국내 전문가들의 검토의견을 기초로 할 때, 최종적으로 한반도 특산으로 인정되는 분 류군은 총 312분류군으로서 여기에는 KFS (2012)와 NIBR (2013)에 공통으로 제시된 249분류군, KFS (2012)에서만 취급된 31분류군, NIBR (2013)에서만 취급된 32분류군이 
Table 1. Summary and comparison between the present and previous studies of KFS (2012) and NIBR (2013).

\begin{tabular}{|c|c|c|c|c|c|c|}
\hline \multirow{2}{*}{ No. of taxa } & \multicolumn{2}{|c|}{ Previous study } & \multicolumn{4}{|c|}{ Present study } \\
\hline & KFS (2012) & NIBR (2013) & KFS (2012) & NIBR (2013) & Newly added & Total \\
\hline Shared & \multicolumn{2}{|c|}{289} & \multicolumn{2}{|c|}{249} & & \\
\hline Exclusive & 69 & 86 & 31 & 32 & & \\
\hline Subtotal & 358 & 375 & 280 & 281 & & \\
\hline Total & \multicolumn{2}{|c|}{444} & \multicolumn{2}{|c|}{312} & 48 & 360 \\
\hline
\end{tabular}

해당된다(Table 1). 그 외에 양 기관의 목록에는 언급되지 않았으나, 2016년까지 한반도 특산으로 기재되거나 언급 된 분류군들 중에서 48 분류군이 특산으로 인정되어 본 재 검토에서 한반도 특산 관속식물은 총 64과 172속 297종 4 아종 51 변종 8 잡종의 360 분류군으로 정리되었다(Table 1).

KFS (2012)와 NIBR (2013)에서 특산으로 취급되었으나 본 연구 결과 특산에서 제외된 분류군은 총 132 분류군으 로, 두 목록 공통 40분류군, KFS (2012) 단독 취급 38분류 군, NIBR (2013) 단독 취급 54분류군이다. 이들을 주요 제 외 사유별로 구분하면 (1) 이명처리 되었거나 개체 변이로 추정되어 이명가능성이 있는 95 분류군, (2) 주변국 분포사 실 확인 25 분류군, (3) 품종으로 취급되는 3 분류군, (4) 학 명표기 오류 및 비합법명 또는 서명 8분류군, 그리고 (5) 학명출처 불확실 1분류군이다(Appendix 2).

\section{고 찰}

본 연구 결과 한반도 특산으로 제시된 360 분류군 중 몇 가지 특이사항은 다음과 같다. 장수만리화의 경우 $\mathrm{KFS}$ (2012)에서는 1942년 발표된 Forsythia velutina Nakai를 학 명으로 정리하고 있으나, NIBR (2013)은 Lee (1966)가 Rangium nakaii Uyeki를 Forsythia Vahl로 조합한 F. nakaii (Uyeki) T. B. Lee를 정명으로 제시하고 있다. 이와 관련하 여 De Juana Clavero (2016)는 Rangium Juss. 가 Forsythia의 이명으로 처리되었기 때문에 1940년 발표된 R. nakaii가 종 계급에서 선취권이 인정되어 $F . n a k a i i$ 를 장수만리화의 정명으로 사용해야 한다고 하였으며, 이는 조류, 균류와 식물에 대한 국제명명규약 (International Code of Nomenclature for Algae, Fungi, and Plants, ICN)의 11조 4항 에 따른 것이다. 따라서 본 목록에서는 장수만리화의 정 명을 F. nakaii로 하였다. 제주도 및 내륙에 자생하는 것으 로 알려졌던 설앵초의 경우 두 목록에서 모두 Primula modesta Bisset \& S. Moore var. hannasanensis T. Yamaz.를 정명으로 특산으로 처리하고 있다. 그러나 Yamazaki (2003)는 제주도 외에 경상남도 내륙에서 설앵초로 동정 되는 집단을 P. farinosa L. subsp. modesta (Bisset \& S. Moore) Pax var. koreana T. Yamaz.로 신변종 처리하였다. 따 라서 P. farinosa subsp. modesta var. koreana를 설앵초의 학 명으로 제시하고, 제주도에 분포하는 P. farinosa L. subsp. modesta (Bisset \& S. Moore) Pax var. hannasanensis (T. Yamaz.) T. Yamaz.는 한라설앵초로 새로운 국명을 부여하 였다.

특산에서 제외된 132 분류군 중 긴괭이싸리[Lespedeza pilosa (Thunb.) Siebold \& Zucc var. pedunculata T. B. Lee] 와 진보라붓꽃(Iris sanguinea Donn ex Hornem. var. violacea Makino)은 해당 분류군 국내 전문가만의 의견을 참고하여 근연종의 개체 변이로 판단되어 제외하였다. 주변국 분포 사실 확인된 25 분류군의 경우, 중국에서 확인된 것이 20 건으로 가장 많았고 일본이 10 건, 러시아 5 건, 몽골과 북아 메리카가 각각 1건이었다. NIBR (2013)에서 한라세모부 추의 학명으로 제시한 Allium taquetii H. Lév. var. deltoides (S. Yu, S. Lee \& W. Lee) H. J. Choi \& B. U. Oh는 Oh (2007b) 의 학명표기 오류가 반영된 것으로 확인되었다. 금강고사 리[Dryopteris austriaca (Jacq.) Woyn. ex Schinz \& Thell. var. subopposita H. Ito]는 현재까지 학명의 출처를 확인할 수 없기에 제외하였다.

새롭게 한반도 특산속으로 추가된 것은 덕우기름나물 속(Sillaphyton Pimenov)이다. 최근에 Pimenov et al. (2016)은 $S$. podagraria (H. Boissieu) Pimenov ( $\equiv$ Peucedanum podagraria H. Boissieu)을 기준으로 본 속을 신설하며 한반 도 특산으로 제시하였다. 반면 한반도 특산 속으로 취급되 어온 금강인가목속(Pentactina Nakai)은 Yakubov (2014)에 의해 러시아 극동지역에 분포하는 Spiraea schlothauerae Ignatov \& Worosch이 P. schlothauerae (Ignatov \& Worosch.) V. Yakubov로 소속을 변경함으로 특산 속에서 제외하여야 할 것으로 판단된다. 결과적으로 한반도 특산속은 미선나 무속(Abeliophyllum Nakai), 매미꽃속(Coreanomecon Nakai), 금강초롱꽃속(Hanabusaya Nakai), 제주고사리삼속(Mankyua B.-Y. Sun, M. H. Kim \& C. H. Kim) 및 모데미풀속 (Megaleranthis Ohwi)을 포함하여 총 6속으로 정리되었다.

\section{Acknowledgments}

This research was supported by the Korea Forest Service in 2015 as a policy research project to the Korean Society of Plant Taxonomists. We thank the following researchers for their cooperation with taxonomic opinions: Cho, Won Bum (Pedicularis), Choi, Byoung-Hee (Fabaceae), Choi, Kyung 
(Pseudostellaria), Chung, Kyong-Sook (Carex), Heo, KyeongIn (Potentilla), Jang, Chang-Gee (Polygonatum), Jang, HyunDo (Scrophularia), Jeong, Keum Seon (Galium) Im, HyoungTak (Saussurea), Kang, Shin-Ho (Chrysosplenium), Kim, JooWhan (Euonymus), Kim, Sangtae (Elsholtzia, Scutellaria), Kim, Yoon-Young (Brassicaceae), Kim, Young-Dong (Chrysosplenium, Berberis), Ko, Sung Chul (Arisaema, Clematis), Lee, Chang Shook (Pteridophytes), Lee, Heung Su (Fraxinus), Lee, Jung Hyun (Quercus), Oh, Byoung-Un (Asarum, Corydalis, Impatiens), Park, Ki-Ryong (Euphorbia, Orostachys, Sedum), Park, SeonJoo (Thalictrum, Geranium), Park, SeongJun (Thalictrum), Park, Wan-Geun (Salix), Sim, Jeong-Ki (Iris), Yanng, Ji Young (Rubus), Lee, Ro-Young (Rubus), Yang, Jong-Cheol (Gymnosperms), Yoo, Ki-Oug (Adenophora, Viola), Yoon, Chang-Young (Angelica).

\section{Literature Cited}

Akiyama, S. 1988. A revision of the genus Lespedeza section Macrolespedeza (Leguminosae). Bulletin, University Museum, University of Tokyo 33: 1-170.

Afanasiev, K. S. and V. P. Botschantzev. 1961. Achillea L. In Flora of the USSR, Vol. 26. Schischkin, B. K. and E. G. Bobrov (eds.), The Botanical Institute of the Academy of Sciences of the U.S.S.R., Leningrad. Pp. 70-124.

Anderson, S. 1994. Area and endemism. The Quarterly Review of Biology 69: 451-471.

Boo, D. and S. J. Park. 2016. Molecular phylogenetic study of Korean Tilia L. Korean Journal of Plant Resources 29: 547554. (in Korean)

Chang, C.-S. and H. Y. Gil. 2014. Sorbus ulleungensis, a new endemic species on Ulleung Island, Korea. Harvard Papers in Botany 19: 247-255.

Chang, C. S., H. Kim and K. S. Chang. 2011. Illustrated Encyclopedia of Fauna \& Flora of Korea. Vol. 43. Woody Plants. Ministry of Education Science and Technology, Paju, 509 pp. (in Korean)

Chen, J. Y. 2008. A taxonomic revision of Syringa L. (Oleaceae). Cathaya; Annals of the Laboratory of Systematic and Evolutionary Botany and Herbarium, Institute of Botany, Chinese Academy of Sciences 17-18: 1-170.

Chen, J. Y., Z. S. Zhang and D. Y. Hong. 2009. A taxonomic revision of the Syringa pubescens complex (Oleaceae). Annals of the Missouri Botanical Garden 96: 237-250.

Choi, B. H. and S. G. Kwon. 2001. Taxonomy of Korean endemic species of Vicia hirticalycina based on morphological and genetic variations. Korean Journal of Plant Taxonomy 31: 1531. (in Korean)
Choi, H.-J. and B.-U. Oh. 2003. Taxonomy of the Allium sect. Sacculiferum in Korea: with a special reference to the morphology. Korean Journal of Plant Taxonomy 33: 339-357. (in Korean)

Choi, H. J. and B. U. Oh. 2011. A partial revision of Allium (Amaryllidaceae) in Korea and northeastern China. Botanical Journal of the Linnean Society 167: 153-211.

Choi, I.-S., S.-Y. Kim and B.-H. Choi. 2015. A taxonomic revision of Astragalus L. (Fabaceae) in Korea. Korean Journal of Plant Taxonomy 45: 227-238

Chung, M. Y., J. M. Chung, J. López-Pujol, S. J. Park and M. G. Chung. 2013. Genetic diversity in three species of Forsythia (Oleaceae) endemic to Korea: implications for population history, taxonomy, and conservation. Biochemical Systematics and Ecology 47: 80-92.

Chung, Y. H. and J. H. Kim. 1990. A taxonomic study of Sedum section Telephium in Korea. Korean Journal of Botany 33: 124. (in Korean)

Clayton, W. D., K. T. Harman and H. Williamson. 2006. World Grass Species - Synonymy database. The Board of Trustees of the Royal Botanic Gardens, Kew.

De Juana, J. I. 2009. Taxonomía actualizada del género Ligustrum L. Bouteloua 6: 16-71. (in Spanish)

De Juana Clavero, J. I. 2016. Proposal to conserve the name Forsythia nakaii (Uyeki) T. Lee against Forsythia velutina Nakai (Oleaceae). Bouteloua 24: 67-69.

Fang, C., S. Zhao and A. K. Skvortsov. 1999. Salix Linnaeus. In Flora of China, Vol. 4. Wu, Z. Y. and P. H. Raven (eds.), Science Press, Beijing and Missouri Botanical Garden Press, St. Louis, MO. Pp. 162-274.

Fang, R. and P. F. Stevens. 2005. Vaccinium Linnaeus. In Flora of China, Vol. 14. Apiaceae through Ericaceae. Wu, Z. Y., P. H. Raven and D. Y. Hong (eds.), Science Press, Beijing and Missouri Botanical Garden Press, St. Louis, MO. Pp. 476-504.

Fuse, S., N. S. Lee and M. N. Tamura. 2004. Biosystematic studies on the genus Heloniopsis (Melanthiaceae) II. Two species from Korea based on morphological and molecular evidence. Taxon 53: 949-958.

Govaerts, R. 1995. World Checklist of Seed Plant 1. MIM, Deume, 483 pp.

Govaerts, R. 2003. World Checklist of Selected Plant Families Database in ACCESS: 1-216203. The Board of Trustees of the Royal Botanic Gardens, Kew.

Govaerts, R. 2004. World Checklist of Selected Plant Families Database in ACCESS: 1-54382. The Board of Trustees of the Royal Botanic Gardens, Kew.

Govaerts, R. 2011. World checklist of selected plant families published update. Facilitated by the Trustees of the Royal Botanic 
Gardens, Kew.

Govaerts, R. and D. A. Simpson. 2007. World Checklist of Cyperaceae. Sedges. The Board of Trustees of the Royal Botanic Gardens, Kew, 765 pp.

Govaerts, R. and W. Bopp. 2017. World Checklist of Betulaceae. Facilitated by the Royal Botanic Gardens, Kew. Retrieved Sep. 1, 2017, available from http://www.kew.org/wcsp/.

Green, P. S. 1995. Taxonomic notes relating to Ligustrum (Oleaceae). Kew Bulletin 50: 379-386.

Han, J.-W. and S.-H. Kang. 2012. Chrysospenium epigealum J.W. Han et S.H. Kang: a new species of Chrysosplenium (Saxifragaceae) from Korea. Korean Journal of Plant Resources 25: 346-348.

Han, S. H. 2016. A taxonomic study of the genus Astilbe (Astilbeceae) in Korea. M.S. thesis, Chungbuk National University, Cheongju, 88 pp. (in Korean)

Hart, H. T. and B. Bleij. 2003. Sedum. In Illustrated Handbook of Succulent Plants: Crassulaceae. Eggli, U. (ed.), Springer, Heidelberg. Pp. 235-332.

Hassler, M. 2017. World plants: synonymic checklists of the vascular plants of the world (version Nov 2016). In Species 2000 \& ITIS Catalogue of Life, 30th January 2017. Retrieved Sep. 1, 2017, available from www.catalogueoflife.org/col.

Hatusima, S. 1967. Lespedeza: Sects. Macrolespedeza and Heterolespedeza from Japan, Corea and Formosa. Memoirs of the Faculty of Agriculture, Kagoshima University 6: 1-17.

Hong, D. Y., H. Yang, C. L. Jin, M. A. Fischer, N. H. Holmgren and R. R. Mill. 1998. Scrophulariaceae A. L. Jussieu. In Flora of China, Vol. 18. Wu, Z. Y. and P. H. Raven (eds.), Science Press, Beijing and Missouri Botanical Garden Press, St. Louis, MO. Pp. 1-212.

Hong, M.-P., Y.-C. Kim, G.-H. Nam and B. Y. Lee. 2012. A new species of Zabelia (Linnaeaceae) from Korea. Journal of Species Research 1: 1-3.

Im, R. J. 1999. Cirsium. Adams. In Flora Coreana, Vol. 6. Im, R. J. (ed.), Science and Technology Publishing House, Pyongyang. Pp. 154-160.

Iwatsuki, K., D. E. Boufford and H. Ohba. 2001. Flora of Japan Vol. IIb. Angiospermae Dicotyledoneae Archlamydeae (b). Kodansha, Tokyo, 321 pp.

Iwatsuki, K., D. E. Boufford and H. Ohba. 2006. Flora of Japan Vol. IIa. Angiospermae Dicotyledoneae Archlamydeae (a). Kodansha, Tokyo, 550 pp.

Jang, C. G. 1998. A systematic study of the genus Polygonatum (Liliaceae): with a special reference to Korean species. Ph.D. dissertation, Korea University, Seoul, 458 pp. (in Korean)

Jang, C. G., M. S. Park, B. M. Nam, H. H. Pak, J. A. Eom and G. Y. Chung. 2011. Distribution and morphological characteris- tics of Scopolia japonica Maxim. in Korea. Korean Journal of Plant Taxonomy 41: 271-279.

Jang, H. D. 2016. A systematic study of the genus Scrophuria (Scrophulariaceae) in Northeast Asia. Ph.D. dissertation, Chungbuk National University, Cheongju, 252 pp. (in Korean)

Jeffrey, C. and Y.-L. Chen. 1984. Taxonomic studies on the tribe Sencioneae (Compositae) of eastern Asia. Kew Bulletin 39: 205-446.

Ji, S.-J., Y.-Y. Kim and B.-U. Oh. 2010. Taxonomic review of Impatiens furcillata Hemsl. (Balsaminaceae). Korean Journal of Plant Taxonomy 40: 43-49. (in Korean)

Jo, H. and M. Kim. 2016. A new variety of Hosta (Liliaceae): Hosta clausa var. geumgangensis M. Kim \& H. Jo. Korean Journal of Plant Taxonomy 46: 306-313.

Kang, U., J. Chung, S. S. Jung, G. Lee and J. Kim. 2012. Carex splendentissima (Cyperaceae), a new species from Korea. The Journal of Japanese Botany 87: 314-319.

Katsuki T. and H. Iketani. 2016. Nomenclature of Tokyo cherry (Cerasus $\times$ yedoensis 'Somei-yoshino', Rosaceae) and allied interspecific hybrids based on recent advances in population genetics. Taxon 65: 1415-1419.

Kholina A. B., M. M. Kozyrenko, E. V. Artyukova, D. V. Sandanov and E. A. Andrianova. 2016. Phylogenetic relationships of the species of Oxytropis DC. subg. Oxytropis and Phacoxytropis (Fabaceae) from Asian Russia inferred from the nucleotide sequence analysis of the intergenic spacers of the chloroplast genome. Russian Journal of Genetics 52: 780-793.

Kikuchi, R., P. Jae-Hong, H. Takahashi and M. Maki. 2010. Disjunct distribution of chloroplast DNA haplotypes in the understory perennial Veratrum album ssp. oxysepalum (Melanthiaceae) in Japan as a result of ancient introgression. New Phytologist 188: 879-891.

Kim, C. H., M. O. Moon and B. Y. Sun. 2015b. Phegopteris (C. Presl) Fée. In Flora of Korea. Vol. I. Pteridophytes \& Gymnosperms. Flora of Korea Editorial Committee (eds.), The National Institute of Biological Resources, Incheon. Pp. 105107.

Kim, C. H. and B. Y. Sun. 2015. Woodsia R. Br. In Flora of Korea. Vol. I. Pteridophytes \& Gymnosperms. Flora of Korea Editorial Committee (eds.), The National Institute of Biological Resources, Incheon. Pp. 81-83.

Kim, C. H., B. Y. Sun, S. J. Lee and C. W. Park. 2015a. Dryopteris Adans. In Flora of Korea. Vol. I. Pteridophytes \& Gymnosperms. Flora of Korea Editorial Committee (eds.), The National Institute of Biological Resources, Incheon. Pp. 130145.

Kim, J. and M. Kim. 2015a. A new species of Fimbristylis (Cyperaceae): F. drizae J. Kim and M. Kim. Korean Journal of Plant 
Taxonomy 45: 8-11.

Kim, J. and M. Kim. 2015b. A new species of Fimbristylis (Cyperaceae): F. jindoensis J. Kim and M. Kim. Korean Journal of Plant Taxonomy 45: 318-322.

Kim, J. H. 1993. A taxonomic study of Euonymus L. in Korea. Ph.D. dissertation, Korea University, Seoul, 234 pp. (in Korean)

Kim, J. H. 2015a. Buxus L. In Flora of Korea. Vol. 5b. Rosidae: Elaeagnaceae to Sapindaceae. Flora of Korea Editorial Committee (eds.), The National Institute of Biological Resources, Incheon. P. 67.

Kim, J. O., M. N. Tamura, S. Fuse and N. S. Lee. 2014. Taxonomic status and phylogeny of Veratrum section Veratrum (Melanthiaceae) in Korea and Japan based on chloroplast and nuclear sequence data. Plant Systematics and Evolution 300: $75-89$.

Kim, J.-S., J.-M. Chung, J.-H. Kim, W. Lee, B.-Y. Lee and J.-H. Pak. 2016a. Floristic study and conservation management strategies of algific talus slopes on the Korean peninsula. Korean Journal of Plant Taxonomy 46: 213-246. (in Korean)

Kim, J, Y. 2017a. A taxonomic study on Aster hispidus complex in Korea. M.S. thesis, Andong National University, Andong, 72 pp. (in Korean)

Kim, K. J. and S. M. Yun. 2012. A new species of Melampyrum (Orobanchaceae) from Southern Korea. Phytotaxa 42: 48-50.

Kim, K. O., S. H. Hong, Y. H. Lee, C. S. Na, B. H. Kang and Y. W. Son. 2009. Taxonomic status of endemic plants in Korea. Journal of Ecology and Field Biology 32: 277-293.

Kim, M., S. So, E. Seo, H. Park, K. Han and K. Heo. 2007. Taxonomical review for Tilingia tsusimensis (Apiaceae). Korean Journal of Plant Taxonomy 37: 529-543. (in Korean)

Kim, M. Y. 2004. Korean Endemic Plants. Solkwahak, Seoul, 408 pp. (in Korean).

Kim, M. Y. 2017b. Korean Endemic Plants. Haejin Media Co. Ltd., Seoul, 654 pp. (in Korean).

Kim, T. J. 1998. Phylogenetic studies of tribe Linnaeae (Caprifoliaceae). Ph.D. dissertation, Chonbuk National University, Jeonju, 283 pp. (in Korean)

Kim, Y. I. 2015b. Systematic studies of Chrysosplenium L. series Pilosa Maxim. (Saxifragaceae). Ph.D. dissertation, Hallym University, Chuncheon, 120 pp. (in Korean)

Kim, Y.-I., S. H. Cho, B.-Y. Kim, J.-H. Lee, D.-H. Kang, S. Kim, R. V. Doudkin and Y.-D. Kim. 2015c. A new combination for Saxifraga octopetala (Saxifragaceae) and its phylogenetic relationship. Korean Journal of Plant Taxonomy 45: 306-317.

Kim, Y.-I. and Y.-D. Kim. 2015c. Chrysosplenium aureobracteatum (Saxifragaceae), a new species from South Korea. Novon 23: 432-436.
Kim, Y. Y. 2015c. A systematic study of the genus Cardamine L. (Brassicaceae) in Korea. Ph.D. didssertation, Chungbuk National University, Cheongju, 238 pp. (in Korean)

Kim, Y.-Y., C. Jang, S.-J. Ji, S. H. Oh, N.-R. Na, H. Leem, T.-W. Kim, W.-R. Lee and Y. P. Lim. 2016b. Arabis erecta (Brassicaceae), a new species from Republic of Korea. Phytotaxa 268: 279-285.

Kim, Y. Y. and B. U. Oh. 2013. A taxonomic study of the genus Actinidia in Korea. Korean Journal of Plant Taxonomy 43: 285-295.

Ko, S. C., Y.-M. Lee, K.-S. Chung, D. C. Son, B. M. Nam and G. Y. Chung. 2014. A new species of Paraphlomis (Lamiaceae) from Korea: an additional genus to the Korean flora. Phytotaxa 175: 51-54.

Korea Forest Service (KFS). 2012. Creation and Furtherance of Arboretums Act. Appendix 1-4, Special Plant (Newly Inserted, Jul. 25, 2011).

Lee, B. Y., M. Kwak, J. E. Han, E.-H. Jung and G.-H. Nam. 2013a. Ganghwal is a new species, Angelica reflexa. Journal of Species Research 2: 245-248.

Lee, C. S., K. Lee, S. H. Yeau and K.-S. Chung. 2015. Two new and one unrecorded natural hybrids between Asplenium ruprechtii and related taxa (Aspleniaceae). Korean Journal of Plant Taxonomy 45: 362-368.

Lee, D.-H., J.-S. Park and B.-H. Choi. 2016. A taxonomic review of Korean Leontopodium R. Br. ex Cassini (Asteraceae). Korean Journal of Plant Taxonomy 46: 149-162.

Lee, J., B.-Y. Lee and Y.-S. Kim. 2000. A taxonomic study of Korean taxa of the Rosaceae genus Sanguisorba. Korean Journal of Plant Taxonomy 30: 269-285.

Lee, J., K.-H. Lee, S. So, C. Choi and M. Kim. 2013b. A new species of Daphne (Thymelaeaceae): D. jejudoensis M. Kim. Korean Journal of Plant Taxonomy 43: 94-98.

Lee, J., C. Choi, K. Han, S. So, Y. Hwang and M. Kim. 2012a. A new species of Viola (Violaceae): V. ulleungdoensis M. Kim \& J. Lee. Korean Journal of Plant Taxonomy 42: 202-206.

Lee, J.-H. 2012. Phylogeography of East Asian evergreen broad leaved trees and taxonomy on the Korean Quercus subgenus Cyclobalanopsis. Ph.D. dissertation, Inha University, Incheon, $148 \mathrm{pp}$.

Lee, K.-B., Y.-G. Yoo and K.-R. Park. 2003. Morphological relationships of Korean species of Sedum L. subgenus Aizoon (Crassulaceae). Korean Journal of Plant Taxonomy 33: 1-15. (in Korean)

Lee, N. S. 2011. Illustrated Flora of Korean Orchids. Ewha Womans University Press, Seoul. Pp. 290-299. (in Korean)

Lee, S., Y. Chung and J. Lee. 1990. A new variety of Adenophora, A. remotiflora var. hirticalyx. Korean Journal of Plant Taxon- 
omy 20: 191-194. (in Korean)

Lee, S., K.-I. Heo and S.-C. Kim. 2012b. A new species of Pseudostellaria (Caryophyllaceae) from Korea. Novon 22: 25-31.

Lee, T. B. 1966. Bibliography of the Illustrated Woody Plants of Korea. Bulletin of Forest Experiment Station, Seoul, 330 pp. (in Korean)

Lee, T. B. 1984. Outline of Korean endemic plants and their distribution. Korean Journal of Plant Taxonomy 14: 21-32.

Lee, Y. N. 1982. New taxa of Korean flora (4). Korean Journal of Botany 25: 175-180. (in Korean)

Lee, Y. N. 1998. New taxa on Korean flora (6). Korean Journal of Plant Taxonomy 28: 25-39.

Lee, Y. N. 2004. Veronica pusanensis Y. Lee, sp. nov. Bulletin of Korea Plant Research 4: 16-17.

Lee, Y. N. 2007. Elymus L. In The Genera of Vascular Plants of Korea. Flora of Korea Editorial Committee (eds.), Academic Publishing Co, Seoul. Pp. 1216-1217.

Lee, Y. N. and K. A. Lee. 2000. Orostachys in Korea. Bulletin of Korea Plant Research 1: 31-47.

Lee, Y. N. and Y. C. Oh. 2006. A new genus and a new species of Cyperaceae. Bulletin of Korea Plant Research 6: 24-30.

Lee, W. T. 1996. Lineamenta Florae Koreae. Academy Press, Seoul, 624 pp. (in Korean)

Leenhouts, P. W. 1962. Florae Malesianae Precursores XXXIII. Loganiaceae. Bulletin du Jardin botanique de l'État a Bruxelles 32: 417-458.

Lim, H.-I., K. S. Chang, H. S, Lee, C.-S. Chang and H. Kim. 2009. A reappraisal of Sambucus pendula Nakai on Ulleung Island and its allies. Korean Journal of Plant Taxonomy 39: 181-192.

Lim, J. and B.-Y. Sun. 2015. A new species of Huperzia (Lycopodiaceae) from Jeju Island, Korea: Huperzia jejuensis. Korean Journal of Plant Taxonomy 45: 17-21.

Lin, Y. X. and R. Viane. 2013. Aspleniaceae. In Flora of China, Vol. 2-3 (Pteridophytes). Z. Y. Wu, P. H. Raven and D. Y. Hong (eds.), Science Press, Beijing and Missouri Botanical Garden Press, St. Lious, MO. Pp. 267-316

Liu, B. and D. Hong. 2016. A taxonomic revision of Pourthiaea villosa complex (Rosaceae). Phytotaxa 244: 201-247.

Liu, L., G. Zhu and N. N. Tzvelev. 2006. Puccinellia Parlatore. In Flora of China, Vol. 22. Poaceae. Z. Y. Wu, P. H. Raven and D. Y. Hong (eds.), Science Press, Beijing and Missouri Botanical Garden Press, St. Louis, MO. Pp. 245-256.

Ma, Y. and S. Kim. 2014. Morphological diagnostic characters of Isodon (Lamiaceae) in Korea. Korean Journal of Plant Taxonomy 44: 261-275. (in Korean)

McNeill J, F. R. Barrie, W. R. Buck, V. Demoulin, W. Greuter, D. L. Hawksworth, P. S. Herendeen, S. Knapp, K. Marhold, J. Prado, W. F. Prud'homme van Reine, G. F. Smith, J. H.
Wiersema and N. J. Turland. 2012. International Code of Nomenclature for algae, fungi, and plants (Melbourne Code) adopted by the Eighteenth International Botanical Congress Melbourne, Australia, July 2011. Regnum Vegetabile 154: 1140.

Miller, C. F. and M. Y. Kim. 2002. Ilex $\times$ wandoensis C. F. Miller $\&$ M. Kim, a new hybrid species of Ilex (Aquifoliaceae) from Korea. Korean Journal of Plant Taxonomy 32: 293-299.

Murata, G. 1984. Taxonomical notes 15 (Continued from Vol. XXXII: 55). Acta Phytotaxonomica et Geobotanica 35: 3036. (in Japanese)

Na, H. R. and S. H. Oh. 2015. Trapa L. In Flora of Korea Vol. 5b. Rosidae: Elaeagnaceae to Sapindaceae. Flora of Korea Editorial Committee (eds.), The National Institute of Biological Resources, Incheon. Pp. 22-24.

National Institute of Biological Resources (NIBR). 2013. Endemic Species of Korea. Plantae. NIBR, Incheon, 912 pp. (in Korean)

Nakai, T. 1917. Notulae ad Plantas Japoniae et Koreae. XIV. Botanical Magazine 31: 97-112.

Nakai, T. 1952. A synoptical sketch of Korean flora. Bulletin of the National Science Museum, Series B, Botany 31: 1-152.

Nordenstam, B. and P. B. Pelser. 2011. Notes on the generic limits of Sinosenecio and Tephroseris (Compositae - Senecioneae). Compositae Newsletter 49: 1-7.

Oh, B. U. 2007a. Arabis L. In The Genera of Vascular Plants of Korea. Flora of Korea Editorial Committee (eds.), Academic Publishing Co., Seoul. Pp. 431-434.

Oh, B. U. 2007b. Allium L. In The Genera of Vascular Plants of Korea. Flora of Korea Editorial Committee (eds.), Academic Publishing Co, Seoul. Pp. 1280-1285.

Oh, B. U. 2008. A taxonomic review of Korean Asarum (Aristolochiaceae). Korean Journal of Plant Taxonomy 38: 251-270. (in Korean)

Oh, B.-U., C.-G. Jang and C.-Y. Yoon. 2004. Corydalis namdoensis B.U. Oh et J.G. Kim: a new species of Corydalis sect. Corydalis (Fumariaceae) from Korea. Korean Journal of Plant Taxonomy 34: 265-271.

Oh, B. U., D. G. Jo, K. S. Kim and C. G. Jang. 2005. Endemic Vascular Plants in Korean Peninsula (1st step result). Korea National Arboretum, Pocheon, 205 pp. (in Korean)

Oh, S.-H. 2015. Sea, wind, or bird: origin of Fagus multinervis (Fagaceae) inferred from chloroplast DNA sequences. Korean Journal of Plant Taxonomy 45: 213-220.

Oh, Y. C. 2007c. Carex L. In The Genera of Vascular Plants of Korea. Flora of Korea Editorial Committee (eds.), Academic Publishing Co., Seoul. Pp. 1139-1181.

Oh, Y. C. and J. S. Hur. 2002. Morphological study of Korean 
Eriocaulaceae. Korean Journal of Plant Taxonomy 32: 109141. (in Korean)

Ohba, H. 2003a. Orostachys. In Illustrated Handbook of Succulent Plants: Vol. V. Crassulaceae. Eggli, U. (ed.), Springer, Heidelberg. Pp.186-190.

Ohba, H. 2003b. Rhodiola. In Illustrated Handbook of Succulent Plants: Crassulaceae. Eggli, U. (ed.), Springer, Heidelberg. Pp. 210-226.

Ohrnberger, D. 1999. The Bamboos of the World: Annotated Nomenclature and Literature of the Species and the Higher and Lower Taxa. Elsevier Science, Amsterdam, 596 pp.

Paik, W. K. 1999. The status of endemic plants in Korea and our tasks in the 21st century. Korean Journal of Plant Taxonomy 29: 263-274. (in Korean)

Paik, W.-K., Y. Chung and W. Lee. 2001. Taxonomic studies of Korean Gentianaceae based on pollen morphology. Korean Journal of Plant Taxonomy 31: 33-56. (in Korean)

Pak, J.-H., Y.-O. Kim and K. Choi. 2001. Taxonomic reconsideration of Lactuca hallaisanensis H. Lév. Korean Journal of Plant Taxonomy 31: 311-319.

Park, K. R. 2015. Euphorbia L. In Flora of Korea. Vol. 5b. Rosidae: Elaeagnaceae to Sapindaceae. Flora of Korea Editorial Committee (eds.), National Institute of Biological Resources, Incheon. Pp. 74-79.

Park, M. S. 2012. A systematic study of the genus Artemisia (Asteraceae) in Korea. Ph.D. dissertation, Andong National University, Andong, 310 pp.

Park, S., H. Kim, H.-S. Lee and C.-S. Chang. 2005. Taxonomic reconsideration of the Philadelphus schrenkii complex. Korean Journal of Plant Taxonomy 35: 247-272. (in Korean)

Park, S. K., H.-Y. Gil, H. Kim and C.-S. Chang. 2013a. A reconsideration of the list of national endemic plants (appendix 4-1) under the creation and furtherance of arboretums act proposed by Korea Forest Service. Journal of Korean Forest Society 102: 38-58. (in Korean)

Park, S.-K., H.-Y. Gil, H. Kim and C.-S. Chang. 2013b. Using morphometrics to unravel species relationships and delimitations in Sorbus pohuashanensis in the Korean peninsula. Korean Journal of Plant Taxonomy 43: 300-311. (in Korean)

Park, W. G. 2007. Salix L. In The Genera of Vascular Plants of Korea. Flora of Korea Editorial Committee (eds), Academy Publishing Co., Seoul. Pp. 410-422.

Pimenov, M. G., T. A. Ostroumova, G. V. Degtjareva and T. H. Samigullin. 2016. Sillaphyton, a new genus of the Umbelliferae, endemic to the Korean Peninsula. Botanica Pacifica 5: $31-41$.

Rong, L., K. Lei and C. Wang. 2011. Collection and evaluation of the genus Lilium resources in Northeast China. Genetic
Resources and Crop Evolution 58: 115-123.

Seok, D.-I. and B.-H. Choi. 1997. Taxonomic study on Vicia unijuga using principal components analysis. Korean Journal of Plant Taxonomy 27: 359-368. (in Korean)

Shin, H., Kim, Y.-D. and S.-H. Oh. 2011. A new combination in Spiraea (Rosaceae) from Ulleung Island, Korea. Novon 21: 373-374.

Siljak-Yakovlev, S. and L. Peruzzi. 2012. Cytogenetic characterization of the endemics: past and future. Plant Biosystems 146: 694-702.

So, S., H. Jo and M. Kim. 2014. A new species of Potentilla (Rosaceae): P. gageodoensis M. Kim. Korean Journal of Plant Taxonomy 44: 175-177.

So, S., Y. Hwang, C.-H. Lee and M. Kim. 2010. A new species of Asarum: A. yeonbyeonense M. Kim \& S. So. Korean Journal of Plant Taxonomy 40: 255-261.

Song, I. and S. Park. 2012. Taxonomic identity of Cardamine leucantha (Brassicaceae) in Korea. Feddes Repertorium 122: 391-408.

Tang, Y., M. G. Gilbert and L. J. Dorr. 2007. Tilia Linnaeus. In Flora of China, Vol. 12. Hippocastanaceae through Theaceae. Z. Y. Wu, P. H. Raven and D. Y. Hong (eds.), Science Press, Beijing and Missouri Botanical Garden Press, St. Louis, MO. Pp. 240-248.

Tamura, M. 1953. Thalictra of Japan, Kuriles, Saghalin, and Corea. Acta Phytotaxonomica et Geobotanica 15: 80-88. (in Japanese)

Tamura, M. N. 2008. Biosystematic studies on the genus Polygonatum (Asparagaceae) V. Taxonomic revision of species in Japan. Acta Phytotaxonomica et Geobotanica 59: 15-29.

Tamura, M. N., N. S. Lee, T. Katsuyama and S. Fuse. 2013. Biosystematic studies on the Family Tofieldiaceae. IV. Taxonomy of Tofieldia coccinea in Japan and Korea including a new variety. Acta Phytotaxonomica et Geobotanica 64: 29-40.

Tucker, A. O. and R. F. C. Naczi. 2007. Mentha: an overview of its classification and relationships. In Mint: The Genus Mentha. Lawrence, B. M. (ed.), CRC Press, Baca Raton, FL. Pp 1-39.

Tzvelev, N. N. and N. S. Probatova. 2012. The taxonomic revision of the genera Deschampsia, Agrostis, Calamagrostis (Poaceae: Poeae) and the system of grasses in the flora of Russia. Komarovskie Chteniya (Vladivostok) 59: 7-75. (in Russian)

Williams, P. H., D. Lees, M. Arahjo, C. J. Humphries, R. I. VaneWright and I. J. Kitching. 2002. Biodiversity and Worldmap. Retrieved Sep. 1, 2017, available from http://www.nhm.ac.uk/ science/projects/world-map/index. html.

Wilmot-Dear, C. M. and I. Friis. 2013. The old World species of Boehmeria (Urticaceae, tribus Boehmerieae): a taxonomic 
revision. Blumea 58: 85-216.

Wu, G. and S. E. Clemants. 2000. Luzula de Candolle in Lamarch $\&$ de Candolle. In Flora of China, Vol. 24. Flagellariaceae through Marantaceae. Z. Y. Wu and P. H. Raven (eds.), Science Press, Beijing and Missouri Botanical Garden Press, St. Louis, MO. Pp. 64-69.

Xu, L. and C. Aedo. 2008. Geranium Linnaeus. In Flora of China, Vol. 11. Z. Y. Wu, P. H. Raven and D. Y. Hong (eds.), Science Press, Beijing and Missouri Botanical Garden Press, St. Louis, MO. Pp. 7-30.

Yahara, T. 1983. A biosystematic study on the local populations of some species of the genus Boehmeria with special reference to apomixes. Journal of the Faculty of Science, Imperial University of Tokyo III. Botany 13: 217-261

Yakubov, V. V. 2014. The genera Pentactina and Geum (Rosaceae) in the Russian Far East. In V. L. Komarov Memorial Lectures: Issue 62. Kozhevnikov, A. E. (ed.), Dalnauka, Vladivostok. Pp. 229-240. (in Russian)

Yamazaki, T. 1954. Melampyrum of Eastern Asia. Journal of Japanese Botany 29: 1-9. (in Japanese)

Yamazaki, T. 1996. A revision of the genus Rhododendron in Japan, Taiwan, Korea and Sakhalin. Tsumura Laboratory, Tokyo, $179 \mathrm{pp}$.

Yamazaki, T. 2003. Intraspecific taxa in Primula farinosa L. subsp. modesta (Bisset and Moore) Pax. Journal of Japanese Botany 78: 295-299. (in Japanese)

Yang, J. Y., S.-C. Kim, S. J. Park and J.-H. Pak. 2016. Typification and validation of names in Korean Rubus (Rosaceae). Novon
25: 114-124.

Yang, J. Y., H.-S. Yoon and J.-H. Pak. 2012. Phylogeny of Korean Rubus (Rosaceae) based on the second intron of the LEAFY gene. Canadian Journal of Plant Science 92: 461-472.

Yang, S. K. 2016. Systematic study of the genus Corydalis (Fumariaceae) in Korea. Ph.D. dissertation, Chungbuk National University, Cheongju, 183 pp. (in Korean)

Yoo, K. O. 1995. Taxonomic studies on the Korean Campanulaceae. Ph.D. dissertation, Kangwon National University, Chuncheon, 278 pp. (in Korean)

Yoon, C. Y. 1994. A taxonomic study on the genus Angelica L. in Korea and the adjacent regions. Ph.D. dissertation, Korea University, Seoul, 199 pp. (in Korean)

Yun, K.-W. and M. Kim. 2009. Taxonomic study of Broussonetia (Moraceae) in Korea. Korean Journal of Plant Taxonomy 39: $80-85$.

Zhu, G., H. Li and R. Li. 2007. A synopsis and a new species of the E Asian genus Pinellia (Araceae). Willdenowia 37: 503522.

Zhu, G., L. Liu, R. J. Soreng and M. V. Olonova. 2006. Poa Linnaeus. In Flora of China, Vol. 22. Poaceae. Z. Y. Wu, P. H. Raven and D. Y. Hong (eds.), Science Press, Beijing and Missouri Botanical Garden Press, St. Louis, MO. Pp. 257-309.

Zhu, S. and N. Kilian. 2011. Crepis coreana (Nakai) H. S. Pak. In Flora of China, Vol. 20?21. Asteraceae. Z. Y. Wu, P. H. Raven and D. Y. Hong (eds.), Science Press, Beijing and Missouri Botanical Garden Press, St. Louis, MO. P. 248. 


\section{Appendix 1. Checklist of Korean endemic vascular plants.}

The information is listed as follow; scientific and vernacular names, distribution and reference. The asterisk $\left({ }^{*}\right)$ indicates additional taxa from KFS (2012) and NIBR (2013). Acronyms for each province are: HB, Hamgyeongbuk-do; HN, Hamgyeongnam-do; PB, Pyeonganbuk-do; PN, Pyeongannam-do; HW, Hwanghae-do; GW, Gangwon-do; GG, Gyeonggi-do; CB, Chungcheongbuk-do; CN, Chungcheongnam-do; GB, Gyeongsangbuk-do; GN, Gyeongsangnam-do; JB, Jeollabuk-do; JN, Jeollanam-do; JJ, Jeju-do.

\section{PTERIDOPHYTA 양치식물문}

\section{Adiantaceae 공작고사리과}

1 Adiantum coreanum Tagawa 고려공작고사리, HB, KFS (2012); NIBR (2013)

Aspleniaceae 꼬리고사리과

*2 Asplenium ×montanus C. S. Lee \& K. Lee 산꼬리고사리, GG, Lee et al. (2015)

*3 Asplenium ×uiryeonse C. S. Lee \& K. Lee 거미사철고사리, GG, Lee et al. (2015)

Athyriaceae 개고사리과

4 Athyrium acutipinnulum Kodama ex Nakai 섬고사리, GB (Ulleungdo), KFS (2012)

Isoetaceae 물부추과

5 Isoetes coreana Y. H. Chung \& H. K. Choi 참물부추, central to southern provinces, KFS (2012); NIBR (2013)

6 Isoetes hallasanensis H. K. Choi, C. Kim \& J. Jung 한라물부추, JJ, KFS (2012); NIBR (2013)

7 Isoetes jejuensis H. K. Choi, C. Kim \& J. Jung 제주물부추, JJ, KFS (2012); NIBR (2013)

Lycopodiaceae석송과

8 Huperzia jejuensis B.-Y. Sun \& J. Lim 긴다람쥐꼬리, JJ, KFS (2012); NIBR (2013); Lim and Sun (2015)

Ophioglossaceae 고사리삼과

9 Mankyua chejuense B.-Y. Sun, M. H. Kim \& C. H. Kim 제주고사리삼, JJ, KFS (2012); NIBR (2013)

GYMNOSPERMAE 나자식물문

\section{Pinaceae 소나무과}

10 Abies koreana E. H. Wilson 구상나무, JB; GN; JJ, KFS (2012); NIBR (2013)

11 Picea pungsanensis Uyeki 풍산가문비나무, HB; HN, KFS (2012); NIBR (2013)

ANGIOSPERMAE 피자식물문

\section{DICOTYLEDONEAE 쌍자엽식물강}

\section{Apiaceae 산형과}

*12 Angelica reflexa B. Y. Lee 강활, GW, Lee et al. (2013a)

13 Bupleurum latissimum Nakai 섬시호, GB (Ulleungdo), KFS (2012); NIBR (2013)

14 Dystaenia takesimana (Nakai) Kitag. 섬바디, GB (Ulleungdo), KFS (2012); NIBR (2013)

15 Peucedanum coreanum Nakai 두메기름나물, GW, KFS (2012); NIBR (2013)

16 Pimpinella brachycarpa (Kom.) Nakai var. uchiyamana (Y. Yabe ex Nakai) W. Lee \& G. Jang 그늘참나물, PB; PN; HW; GW; GG, KFS (2012); NIBR (2013)

17 Pimpinella hallaisanensis (W. Lee \& G. Jang) G. Jang, W. Paik \& W. Lee 한라참나물, JJ (Hallasan), KFS (2012); NIBR (2013) 18 Sillaphyton podagraria (H. Boissieu) Pimenov 덕우기름나물, GW, KFS (2012); NIBR (2013)

19 Sium ternifolium B. Y. Lee \& S. C. Ko 세잎개발나물, GW (Chiaksan), KFS (2012); NIBR (2013)

Aquifoliaceae 감탕나무과

*20 Ilex ×wandoensis C. F. Miller \& M. Kim 완도호랑가시나무, JN (Wando), Miller and Kim (2002)

\section{Araliaceae 두릅나무과}

21 Eleutherococcus divaricatus (Siebold \& Zucc.) S.Y. Hu var. chiisanensis (Nakai) C. H. Kim \& B.-Y. Sun 지리산오갈피나무, HB; HN; GW; GB; JB; JN; JJ, KFS (2012); NIBR (2013)

\section{Aristolochiaceae 쥐방울덩굴과}

22 Asarum maculatum Nakai 개족도리풀, JN; GN; JJ, KFS (2012); NIBR (2013)

23 Asarum patens (Yamaki) Yamaki ex Y. Lee 금오족도리풀, CN; GB, KFS (2012)

*24 Asarum versicolor (Yamaki) Y. Lee 무늬족도리풀, GW; GG; CB, Oh (2008) 


\section{Asteraceae 국화과}

25 Achillea alpina L. subsp. rhodoptarmica (Nakai) Kitam. 붉은톱풀, HB, KFS (2012); NIBR (2013)

26 Artemisia hallaisanensis Nakai 섬쑥, JJ (Hallasan), KFS (2012); NIBR (2013)

27 Aster chusanensis Y. S. Lim, J. O. Hyun, Y. D. Kim \& H. Shin 추산쑥부쟁이, GB (Ulleungdo), KFS (2012)

28 Aster hayatae H. Lév. \& Vaniot 눈갯쑥부쟁이, JJ (Hallasan), KFS (2012); NIBR (2013)

29 Aster koraiensis Nakai 벌개미취, all provinces (mainly planted), KFS (2012); NIBR (2013)

*30 Aster magnus Y. Lee \& C. Kim 왕갯쑥부쟁이, JJ, Lee (1998)

31 Aster pseudoglehnii Y. S. Lim, J. O. Hyun \& H. Shin 섬쑥부쟁이, GB (Ulleungdo), KFS (2012)

32 Aster uchiyamai Nakai 단양쑥부쟁이, GG (Yeoju); CB (Danyang), KFS (2012); NIBR (2013)

33 Chrysanthemum coreanum (H. Lév. \& Vaniot) Nakai 한라구절초, JJ (Hallasan), KFS (2012); NIBR (2013)

34 Chrysanthemum sinchangense Uyeki 신창구절초, PN, KFS (2012); NIBR (2013)

35 Chrysanthemum zawadskii Herbich. subsp. lucidum (Nakai) Y. Lee 울릉국화, GB (Ulleungdo), KFS (2012); NIBR (2013)

36 Cirsium rhinoceros (H. Lév \& Vaniot) Nakai 바늘엉겅퀴, GG; GN; JJ, KFS (2012); NIBR (2013)

37 Cirsium setidens (Dunn) Nakai 고려엉겅퀴, all provinces except JJ, KFS (2012); NIBR (2013)

38 Cirsium setidens (Dunn) Nakai var. niveoaraneum Kitam. 흰잎고려엉겅퀴, HN; PN; GW; GG; CB; CN; GB; GN; JB; JN, NIBR (2013)

39 Cirsium zenii Nakai 점봉산엉겅퀴, GW (Jeombongsan), NIBR (2013)

*40 Crepidiastrum hallaisanense (H. Lév.) J. H. Pak 한라고들빼기, JJ (Hallasan), Pak et al. (2001)

41 Crepidiastrum koidzumianum (Kitam.) J. H. Pak \& Kawano 지리고들빼기, GN (Jirisan), KFS (2012); NIBR (2013)

42 Hololeion maximowiczii Kitam. var. fauriei (H. Lév. \& Vaniot) J.H. Pak 좀께묵, GG; GB; GN; JB; JN, KFS (2012); NIBR (2013)

43 Ixeris $\times$ chinodebilis Kitam. 함흥씀바귀, HN, KFS (2012); NIBR (2013)

44 Leontopodium coreanum Nakai 솜다리, GW; GG; CB; GB, KFS (2012); NIBR (2013)

45 Leontopodium coreanum Nakai var. hallaisanense (Hand.-Mazz.) D. H. Lee \& B. H. Choi 한라솜다리, JJ (Hallasan), KFS (2012); NIBR (2013)

46 Leontopodium leiolepis Nakai 산솜다리, HB; HN; PB; GW, KFS (2012); NIBR (2013)

47 Ligularia fischeri (Ledeb.) Turcz. var. spiciformis Nakai 한대리곰취, HN, KFS (2012); NIBR (2013)

48 Ligularia taquetii (H. Lév. \& Vaniot) Nakai 갯취, GN (Geojedo); JJ, KFS (2012); NIBR (2013)

49 Parasenecio pseudotamingasa (Nakai) B. U. Oh 어리병풍, CB; GN, KFS (2012); NIBR (2013)

50 Saussurea calcicola Nakai 사창분취, GW, KFS (2012); NIBR (2013)

51 Saussurea chabyoungsanica H.T. Im 자병취, GW, KFS (2012); NIBR (2013)

52 Saussurea conandrifolia Nakai 담배취, HB; PB, KFS (2012); NIBR (2013)

53 Saussurea diamantiaca Nakai 금강분취, HN; PN; GW(Geumgansan; Seoraksan), KFS (2012); NIBR (2013)

54 Saussurea eriophylla Nakai 솜분취, GW, KFS (2012); NIBR (2013)

55 Saussurea grandicapitula W. Kee et H. T. Im 태백취, GW (Taekbaeksan), KFS (2012)

56 Saussurea koidzumiana Kitam. 경성서덜취, HB; GW (Goseong), KFS (2012); NIBR (2013)

57 Saussurea komaroviana Lipsch. 비단분취, HB; HN, KFS (2012); NIBR (2013)

58 Saussurea macrolepis (Nakai) Kitam. 각시서덜취, GG; GB; GN; JN, KFS (2012); NIBR (2013)

59 Saussurea myokoensis Kitam. 묘향분취, PB, KFS (2012); NIBR (2013)

60 Saussurea polylepis Nakai 홍도서덜취, JN (Hongdo; Maegado), KFS (2012); NIBR (2013)

61 Saussurea rectinervis Nakai 백설취, HB; HN; PB; PN, KFS (2012); NIBR (2013)

62 Saussurea rorinsanensis Nakai 털분취, PB, KFS (2012); NIBR (2013)

63 Saussurea seoulensis Nakai 분취, GW; GG, KFS (2012); NIBR (2013)

64 Saussurea uchiyamana Nakai 그늘취, GG, KFS (2012); NIBR (2013)

65 Saussurea umbrosa Kom. var. herbicola Nakai 긴산취, HN, NIBR (2013)

66 Taraxacum hallaisanense Nakai 좀민들레, JJ (Hallasan), KFS (2012); NIBR (2013)

Balsaminaceae 봉선화과

67 Impatiens atrosanguinea (Nakai) B. U. Oh \& Y. P. Hong 가야물봉선, GN (Gayasan), NIBR (2013)

*68 Impatiens furcillata Hemsl. 처진물봉선, GN; JN, Ji et al. (2010) 


\section{Berberidaceae 매자나무과}

69 Berberis amurensis Rupr. var. quelpaertensis (Nakai) Nakai 섬매발톱나무, JJ (Hallasan), KFS (2012); NIBR (2013)

70 Berberis koreana Palib. 매자나무, GW; GG; CB, KFS (2012); NIBR (2013)

71 Berberis koreana Palib. var. angustifolia Nakai 가는잎매자나무, GW (Geombulsan), NIBR (2013)

72 Berberis koreana Palib. var. ellipsoidea Nakai 연밥매자나무, GW (Geombulsan; Jangjigansan), KFS (2012)

\section{Betulaceae 자작나무과}

73 Carpinus laxiflora (Siebold et Zucc.) Blume var. longispica Uyeki 긴서어나무, JB; JN; GN, KFS (2012); NIBR (2013)

\section{Brassicaceae 십자화과}

74 Arabis columnaris Nakai 참장대나물, JN (Jirisan), KFS (2012); NIBR (2013)

*75 Arabis erecta Y. Y. Kim \& C. G. Jang 선갯장대, GB, Kim et al. (2016b)

76 Arabis takesimana Nakai 섬장대, GB (Ulleungdo), NIBR (2013)

*77 Cardamine amariformis Nakai 꽃황새냉이, GW; CB; GB; GN, Kim (2015c)

78 Rorippa apetala Y. Y. Kim \& B. U. Oh 섬강개갓냉이, GW (Wonju), KFS (2012)

\section{Campanulaceae 초롱꽃과}

79 Adenophora erecta S. Lee, J. Lee \& S. Kim 선모시대, GB (Ulleungdo), KFS (2012); NIBR (2013)

80 Adenophora kayasanensis Kitam. 가야산잔대, GB; GN (Gayasan), KFS (2012); NIBR (2013)

81 Adenophora koreana Kitam. 꽃잔대, HN; PB; GW (Geumgansan), KFS (2012); NIBR (2013)

82 Adenophora racemosa J. K. Lee \& S. T. Lee 외대잔대, GW; GB, KFS (2012); NIBR (2013)

83 Adenophora remotidens Hemsl. 인천잔대, GG (Incheon), KFS (2012); NIBR (2013)

*84 Adenophora remotiflora (Siebold \& Zucc.) Miq. var. hirticalyx S. Lee, Y. Chung, \& J. Lee 그늘모시대, JB (Jirisan), Lee et al. (1990)

85 Adenophora taquetii H. Lév. 섬잔대, JJ (Hallasan), KFS (2012); NIBR (2013)

86 Adenophora verticillata Fisch. var. abbreviata H. Lév. 좀층층잔대, JJ (Hallasan), KFS (2012); NIBR (2013)

87 Campanula takesimana Nakai 섬초롱꽃, GB (Ulleungdo), KFS (2012); NIBR (2013)

88 Codonopsis minima Nakai 애기더덕, JJ (Hallasan), KFS (2012); NIBR (2013)

89 Hanabusaya asiatica (Nakai) Nakai 금강초롱꽃, HN; PN; GW; GG, KFS (2012); NIBR (2013)

90 Hanabusaya latisepala Nakai 검산초롱꽃, PB; HN, KFS (2012); NIBR (2013)

\section{Caprifoliaceae 인동과}

91 Lonicera insularis Nakai 섬괴불나무, GB (Ulleungdo), NIBR (2013)

92 Lonicera maximowiczii (Rupr.) Regel var. latifolia (Ohwi) H. Hara 흰등괴불나무, JN (Jirisan); JJ (Hallasan), KFS (2012)

93 Lonicera subsessilis Rehder 청괴불나무, all provinces except CN and JJ, KFS (2012); NIBR (2013)

94 Sambucus racemosa L. subsp. pendula (Nakai) H. I. Lim \& Chin. S. Chang 말오줌나무, GB (Ulleungdo), Lim et al. (2009); KFS (2012)

95 Weigela subsessilis (Nakai) L. H. Bailey 병꽃나무, all provinces, KFS (2012); NIBR (2013)

*96 Zabelia densipila M. P. Hong, Y. C. Kim \& B. Y. Lee 긴털댕강나무, GW (Yeongwol), Hong et al. (2012)

97 Zabelia tyaihyonii (Nakai) Hisauti \& H. Hara 줄댕강나무, PN; CB (Danyang), KFS (2012); NIBR (2013)

\section{Caryophyllaceae 석죽과}

98 Pseudostellaria coreana (Nakai) Ohwi 참개별꽃, GG; GN; JJ, KFS (2012)

*99 Pseudostellaria longipedicellata S. Lee, K. Heo \& S. C. Kim 태백개별꽃, GW; GG; GB, Lee et al. (2012b)

100 Pseudostellaria monantha Ohwi 산개별꽃, GN (Jirisan); JJ, KFS (2012); NIBR (2013)

101 Pseudostellaria okamotoi Ohwi 지리산개별꽃, GN (Jirisan), KFS (2012); NIBR (2013)

102 Pseudostellaria setulosa Ohwi 숲개별꽃, HN; GW; GB, KFS (2012); NIBR (2013)

103 Silene fasciculata Nakai 한라장구채, JJ (Hallasan), KFS (2012); NIBR (2013)

104 Silene myongcheonensis S. P. Hong \& H. K. Moon 명천장구채, HB (Chilbosan), KFS (2012); NIBR (2013)

105 Silene takeshimensis Uyeki \& Sakata 울릉장구채, GB (Ulleungdo), KFS (2012); NIBR (2013)

\section{Chenopodiaceae 명아주과}

106 Axyris koreana Nakai 털나도댑싸리, HB; HN, KFS (2012); NIBR (2013)

\section{Clusiaceae 물레나물과}


107 Hypericum chejuense S.-J. Park \& K.-J. Kim 제주고추나물, JJ, KFS (2012)

108 Hypericum jeongjocksanense S.-J. Park \& K.-J. Kim 정족산고추나물, GN (Jeongjoksan), KFS (2012)

\section{Crassulaceae 돌나물과}

109 Hylotelephium viridescens (Nakai) H. Ohba 섬꿩의비름, JN; JJ, KFS (2012); NIBR (2013)

*110 Orostachys margaritifolia Y. Lee 진주바위솔, GN (Jinju), Lee and Lee (2000)

111 Orostachys saxatilis (Nakai) Nakai 모란바위솔, PN, KFS (2012); NIBR (2013)

112 Sedum latiovalifolium Y. Lee 태백기린초, GW, KFS (2012); NIBR (2013)

113 Seum takesimense Nakai 섬기린초, GB (Ulleungdo), KFS (2012); NIBR (2013)

*114 Sedum taquetii Praeger 한라뀡의비름, JJ (Hallasan), Chung and Kim (1990)

\section{Euphorbiaceae 대극과}

115 Euphorbia fauriei H. Lév. \& Vaniot 두메대극, JJ (Hallasan), KFS (2012); NIBR (2013)

116 Glochidion chodoense C. S. Lee \& H. T. Im 조도만두나무, JN (Jodo; Jindo), KFS (2012)

\section{Fabaceae 콩과}

117 Astragalus mongholicus Bunge var. nakaianus (Y. Lee) I.S. Choi \& B.H. Choi 제주황기, JJ (Hallasan), NIBR (2013); Choi et al. (2015)

*118 Astragalus setsureianus Nakai 설령황기, HB; HN, Choi et al. (2015)

119 Indigofera grandiflora B. H. Choi \& S. Cho 큰꽃땅비싸리, GB (Gayasan), KFS (2012); NIBR (2013)

120 Indigofera koreana Ohwi 좀땅비싸리, CN; JB; JN, KFS (2012); NIBR (2013)

121 Lespedeza maritima Nakai 해변싸리, GW; CN; GB; GN, KFS (2012); NIBR (2013)

122 Lespedeza maximowiczii C. K. Schneid. var. tricolor (Nakai) Nakai 삼색싸리, JN (Wando; Jindo); GN, NIBR (2013)

123 Maackia fauriei (H. Lév.) Takeda 솔비나무, JJ (Hallasan), KFS (2012); NIBR (2013)

124 Sophora koreensis Nakai 개느삼, HN; GW (Inje; Yanggu; Chuncheon), KFS (2012); NIBR (2013)

125 Vicia chosenensis Ohwi 노랑갈퀴, all provinces except JJ, KFS (2012); NIBR (2013)

126 Vicia hirticalycina Nakai 나래완두, GB; GN; JB; JN, KFS (2012); NIBR (2013)

*127 Vicia unijuga A. Br. var. kausanensis H. Lév. 애기나비나물, JJ, Seok and Choi (1997)

Fagaceae 참나무과

*128 Fagus multinervis Nakai 너도밤나무, GB (Ulleungdo), Oh (2015)

\section{Fumariaceae 현호색과}

129 Corydalis alata B. U. Oh \& W.R. Lee 날개현호색, GW; GB, KFS (2012)

130 Corydalis albipetala B. U. Oh 흰현호색, GW, KFS (2012); NIBR (2013)

131 Corydalis cornupetala Y. H. Kim \& J.H. Jeong 쇠뿔현호색, GB, KFS (2012)

132 Corydalis filistipes Nakai 섬현호색, GB (Ulleungdo), KFS (2012); NIBR (2013)

133 Corydalis grandicalyx B. U. Oh \& Y.S. Kim 갈퀴현호색, GW; GG; GB, KFS (2012); NIBR (2013)

134 Corydalis hallaisanensis H. Lév. 탐라현호색, JJ, KFS (2012); NIBR (2013)

135 Corydalis hirtipes B. U. Oh \& J. G. Kim 털현호색, GW, NIBR (2013)

136 Corydalis humilis B. U. Oh \& Y. S. Kim 난장이현호색, GG; CB (Sobaeksan); GB (Tohamsan), NIBR (2013)

137 Corydalis maculata B. U. Oh \& Y. S. Kim 점현호색, GW; GG; GB, KFS (2012); NIBR (2013)

138 Corydalis misandra B. U. Oh 각시현호색, GW; GG, KFS (2012)

*139 Corydalis namdoensis B. U. Oh \& J. G. Kim 남도현호색, GB; JB, Oh et al. (2004)

*140 Corydalis ohii Lidén 선현호색, GW; GG; CB; JB; JJ, Yang (2016)

\section{Gentianaceae 용담과}

141 Gentiana chosenica Okuyama 흰그늘용담, JJ (Hallasan), KFS (2012); NIBR (2013)

*142 Gentiana squarrosa Ledeb. var. microphylla Nakai 좀구슬붕이, JJ (Hallasan), Paik et al. (2001)

143 Gentiana takahashii T. Mori 백두산구슬붕이, HB (Baekdusan), KFS (2012); NIBR (2013)

144 Gentiana wootchuliana W. Paik 고산구슬붕이, GN (Gayasan), KFS (2012); NIBR (2013)

\section{Geraniaceae 쥐손이풀과}

145 Geranium knuthii Nakai 큰세잎쥐손이, HN; PB; HW; GG, KFS (2012); NIBR (2013)

146 Geranium koreanum Kom. var. hirsutum Nakai 털둥근이질풀, GW; GG; GB; GN; JJ, KFS (2012); NIBR (2013) 
147 Geranium lasiocaulon Nakai 갈미쥐손이, HB, KFS (2012); NIBR (2013)

148 Geranium taebaek S. J. Park \& Y. S. Kim 태백이질풀, GW (Taebaeksan), KFS (2012); NIBR (2013)

\section{Lamiaceae 꿀풀과}

149 Ajuga spectabilis Nakai 자란초, central to southern provinces, KFS (2012); NIBR (2013)

150 Elsholtzia byeonsanensis M. Kim 변산향유, JB (Byeonsan), NIBR (2013)

151 Elsholtzia minima Nakai 좀향유, JJ (Hallasan), KFS (2012); NIBR (2013)

152 Elsholtzia splendens Nakai ex F. Maek. var. fasciflora N. S. Lee, M. S. Chung \& C. S. Lee 다발꽃향유, JJ (Seogwipo), KFS (2012)

153 Isodon inflexus (Thunb.) Kudô var. canescens (Nakai) Kudô 털산박하, JJ (Chujado), NIBR (2013); Ma and Kim (2014)

154 Lamium takeshimense Nakai 섬광대수염, GB (Ulleungdo), KFS (2012); NIBR (2013)

*155 Paraphlomis koreana S. C. Ko \& G. Y. Chung 속단아재비, JN (Bogildo), Ko et al. (2014)

156 Salvia chanryoenica Nakai 참배암차즈기, GW; GG; CB; GW; GN, KFS (2012); NIBR (2013)

157 Scutellaria asperiflora Nakai 다발골무꽃, HN, KFS (2012); NIBR (2013)

158 Scutellaria indica L. var. coccinea S. Kim \& S. Lee 연지골무꽃, JJ, KFS (2012); NIBR (2013)

159 Scutellaria insignis Nakai 광릉골무꽃, central provinces, KFS (2012); NIBR (2013)

160 Scutellaria pekinensis Maxim. var. maxima S. Kim \& S. Lee 왕골무꽃, GW; GG; CB, NIBR (2013)

161 Thymus quinquecostatus Celak. var. magnus (Nakai) Kitam. 섬백리향, GB (Ulleungdo), KFS (2012)

Moraceae 뽛나무과

*162 Broussonetia $\times$ hanjiana M. Kim 닥나무, JN (Gageodo), Yun and Kim (2009)

Nymphaeaceae 수련과

163 Nymphaea tetragona Georgi var. minima (Nakai) W.T. Lee 각시수련, HW; GW (Goseong), KFS (2012); NIBR (2013)

Oleaceae 물푸레나무과

164 Abeliophyllum distichum Nakai 미선나무, CB (Goesan; Yeongdong; Jincheon); JB (Buan); GB (Andong), KFS (2012); NIBR (2013)

165 Forsythia koreana (Rehder) Nakai 개나리, nearly all provinces; probably originating in central Korea, KFS (2012); NIBR (2013)

166 Forsythia ovata Nakai 만리화, HW; GW; GG; JB, KFS (2012); NIBR (2013)

167 Forsythia nakaii (Uyeki) T. B. Lee 장수만리화, HW (Jansusan), KFS (2012); NIBR (2013)

168 Fraxinus chiisanensis Nakai 물들메나무, JB (Deogyusan); JN (Jirisan), KFS (2012); NIBR (2013)

169 Ligustrum foliosum Nakai 섬쥐똥나무, GB (Ulleungdo), KFS (2012); NIBR (2013)

Orobanchaceae 열당과

170 Orobanche filicicola Nakai ex J. O. Hyun, Y. S. Im \& H. C. Shin 백양더부살이, JB; JN; JJ, KFS (2012); NIBR (2013)

Papaveraceae 양귀비과

171 Coreanomecon hylomeconoides Nakai 매미꽃, GN; JB; JN, KFS (2012); NIBR (2013)

Phytolaccaceae 자리공과

172 Phytolacca insularis Nakai 섬자리공, GB (Ulleungdo), KFS (2012); NIBR (2013)

Polygonaceae 마디풀과

173 Aconogonon brachytrichum (Ohwi) Sojak 털싱아, HB, KFS (2012); NIBR (2013)

174 Aconogonon microcarpum (Kitag.) H. Hara 참개싱아, HN; GW; GG, KFS (2012); NIBR (2013)

175 Aconogonon mollifolium (Kitag.) H. Hara 얇은개싱아, HB; HN; PB, KFS (2012); NIBR (2013)

176 Bistorta globispica Nakai 둥근범꼬리, HB, KFS (2012); NIBR (2013)

177 Fallopia koreana B. U. Oh \& J. G. Kim 삼도하수오, CB; GB; JN, KFS (2012); NIBR (2013)

178 Rheum coreanum Nakai 장군풀, HB; HN, KFS (2012); NIBR (2013)

\section{Primulaceae 앵초과}

179 Androsace cortusifolia Nakai 금강봄맞이, GW, KFS (2012); NIBR (2013)

180 Lysimachia coreana Nakai 참좁쌀풀, HN; GW; GG; CB; GB, KFS (2012); NIBR (2013)

181 Lysimachia quelpaertensis K. H. Tae \& J. S. Lee 탐라까치수염, JJ (Seogwipo), KFS (2012)

182 Primula farinosa L. subsp. modesta (Bisset \& S. Moore) Pax var. hannasanensis (T. Yamaz.) T. Yamaz. 한라설앵초, JJ (Hallasan), KFS (2012); NIBR (2013)

*183 Primula farinosa L. subsp. modesta (Bisset \& S. Moore) Pax var. koreana T. Yamaz. 설앵초, GN, Yamazaki (2003) 


\section{Ranunculaceae 미나리아재비과}

184 Aconitum austrokoreense Koidz. 세뿔투구꽃, GB; GN, KFS (2012); NIBR (2013)

185 Aconitum chiisanense Nakai 지리바꽃, GW; GN, KFS (2012); NIBR (2013)

186 Aconitum pseudolaeve Nakai 진범, all provinces except JJ, KFS (2012); NIBR (2013)

187 Aconitum pteropus Nakai 날개진범, GW, KFS (2012); NIBR (2013)

188 Aconitum quelpaertense Nakai 한라투구꽃, JJ (Hallasan), KFS (2012); NIBR (2013)

189 Anemone koraiensis Nakai 홀아비바람꽃, northern to central provinces, KFS (2012); NIBR (2013)

190 Callianthemum insigne (Nakai) Nakai 매화바람꽃, HB, KFS (2012); NIBR (2013)

191 Cimicifuga austrokoreana H.-W. Lee \& C.-W. Park 나제승마, CB; GN; JB; JN, KFS (2012); NIBR (2013)

192 Cimicifuga heracleifolia Kom. var. bifida Nakai 세잎승마, HN; GW; CN; GN, KFS (2012); NIBR (2013)

193 Clematis brachyura Maxim. 외대으아리, all provinces except CN and JJ, KFS (2012); NIBR (2013)

194 Clematis calcicola J. S. Kim 바위종덩굴, GW (Samcheok), KFS (2012); NIBR (2013)

"195 Clematis taeguensis Y. Lee 대구으아리, GW; CB; GB, Lee (1982)

196 Clematis trichotoma Nakai 할미밀망, all provinces except HB and JJ, KFS (2012); NIBR (2013)

197 Eranthis byunsanensis B.-Y. Sun 변산바람꽃, GW; GG; GB; GN; JB; JN; JJ, KFS (2012); NIBR (2013)

198 Eranthis pungdoensis B. U. Oh 풍도바람꽃, GG (Pungdo), KFS (2012); NIBR (2013)

199 Hepatica insularis Nakai 새끼노루귀, JN; GN; JJ, KFS (2012); NIBR (2013)

200 Hepatica maxima (Nakai) Nakai 섬노루귀, GB (Ulleungdo), KFS (2012); NIBR (2013)

201 Megaleranthis saniculifolia Ohwi 모데미풀, PB; GW; GB; JB; JJ, KFS (2012); NIBR (2013)

202 Pulsatilla nivalis Nakai 산할미꽃, HB, KFS (2012); NIBR (2013)

203 Pulsatilla tongkangensis Y. Lee \& T. C. Lee 동강할미꽃, GW; CB, KFS (2012); NIBR (2013)

204 Ranunculus crucilobus H. Lév. 바위미나리아재비, JJ (Hallasan), NIBR (2013)

205 Thalictrum acteifolium Siebold et Zucc. var. brevistylum Nakai 은꿩의다리, GW; GG; CB, CN; GB; GN; JB; JN, NIBR (2013)

"206 Thalictrum ichangense Lecoy. ex Oliv. var. coreanum (H. Lév.) H. Lév. ex Tamura 연잎껑의다리, GW; GB, Tamura (1953)

207 Thalictrum osmorhizoides Nakai 그늘꿩의다리, HB, KFS (2012); NIBR (2013)

Rhamnaceae 갈매나무과

208 Rhammus taquetii (H. Lév. \& Vaniot) H. Lév. 좀갈매나무, JJ (Hallasan), KFS (2012); NIBR (2013)

\section{Rosaceae 장미과}

209 Aruncus aethusifolius (H. Lév.) Nakai 한라개승마, JJ (Hallasan), KFS (2012); NIBR (2013)

210 Cotoneaster wilsonii Nakai 섬개야광나무, GB (Ulleungdo), KFS (2012); NIBR (2013)

211 Filipendula formosa Nakai 지리터리풀, JB; JN; GN, KFS (2012); NIBR (2013)

212 Pentactina rupicola Nakai 금강인가목, GW (Geumgangsan), KFS (2012); NIBR (2013)

"213 Potentilla gageodoensis M. Kim 가거양지꽃, JN (Gageodo), So et al. (2014)

214 Prunus choreiana Nakai ex H.T. Im 복사앵도, HB; PN; GW; GB, KFS (2012); NIBR (2013)

215 Prunus ishidoyana Nakai 산이스라지, HB, KFS (2012); NIBR (2013)

"216 Prunus nudiflora (Koehne) Koidz. 왕벚나무, JN (Haenam); JJ, Katsuki and Iketani (2016)

217 Prunus takesimensis Nakai 섬벚나무, GB (Ulleungdo), KFS (2012); NIBR (2013)

218 Pyrus hakunensis Nakai 백운배나무, JN (Baegunsan), NIBR (2013)

"219 Rubus coreanus Miq. var. concolor Nakai ex J.Y. Yang 청복분자딸기, GN (Jirisan); JJ, Yang et al. (2016)

220 Rubus hongnoensis Nakai 가시딸기, JJ, KFS (2012); NIBR (2013)

221 Rubus schizostylus H. Lév. 가시복분자딸기, JN; GN; JJ, KFS (2012); NIBR (2013)

222 Rubus takesimensis Nakai 섬나무딸기, GB (Ulleungdo), KFS (2012); NIBR (2013)

223 Rubus tozawae Nakai ex J. Y. Yang 거제딸기, GN (Geojedo); JN (Geomundo), KFS (2012)

224 Sanguisorba argutidens Nakai 구름오이풀, HB; HN; PB, NIBR (2013)

225 Spiraea chartacea Nakai 떡조팝나무, JN (Hongdo; Daeheugsando), KFS (2012); NIBR (2013)

226 Spiraea insularis (Nakai) H. Shin, Y. D. Kim \& S. H. Oh 섬국수나무, GB (Ulleungdo), Shin et al. (2011); KFS (2012); NIBR (2013)

227 Spiraea microgyna Nakai 좀조팝나무, northern to central provinces, NIBR (2013)

228 Spiraea pseudocrenata Nakai 긴잎산조팝나무, HW, NIBR (2013) 
*229 Sorbus ulleungensis Chin S. Chang 우산마가목, GB (Ulleungdo), Chang and Gil (2014)

\section{Rubiaceae 꼭두서니과}

230 Asperula lasiantha Nakai 갈퀴아재비, PN (Seongcheon); GN (Jirisan), KFS (2012); NIBR (2013)

231 Galium koreanum (Nakai) Nakai 참갈퀴덩굴, HW; CN; GB; GN; JB; JN; JJ, KFS (2012); NIBR (2013)

232 Rubia argyi H. Lév. \& Vaniot var. pubescens (Nakai) M. Kim 우단꼭두서니, central to southern provinces, KFS (2012); NIBR (2013); Kim (2017b)

\section{Salicaceae 버드나무과}

233 Populus $\times$ tomentiglandulosa T. B. Lee 은사시나무, GW; GG, KFS (2012); NIBR (2013)

234 Salix bicarpa Nakai 쌍실버들, HB; PB; PN, KFS (2012); NIBR (2013)

235 Salix blinii H. Lév. 제주산버들, JJ, KFS (2012); NIBR (2013)

236 Salix chaenomeloides Kimura var. pilosa (Nakai) Kimura 털왕버들, CB; GB; GN; JN, KFS (2012); NIBR (2013)

237 Salix dependens Nakai 개수양버들, HB; PB; GW; CB, KFS (2012); NIBR (2013)

238 Salix hallaisanensis H. Lév. 떡버들, all provinces, KFS (2012); NIBR (2013)

239 Salix hallaisanensis H. Lév. var. longifolia Nakai 긴잎떡버들, HB; HN; GW; GG; JN; JJ, NIBR (2013)

240 Salix ishidoyana Nakai 섬버들, GB (Ulleungdo), KFS (2012); NIBR (2013)

241 Salix koriyanagi Kimura ex Goerz 키버들, all provinces, KFS (2012)

\section{Saxifragaceae 범의귀과}

242 Astilbe taquetii (H. Lév.) Koidz. 한라노루오줌, JJ (Hallasan), KFS (2012); NIBR (2013)

"243 Chrysosplenium aureobracteatum Y. I. Kim \& Y. D. Kim 연노랑괭이눈, GW, Kim and Kim (2015c)

244 Chrysospenium barbatum Nakai 흰괭이눈, all provinces, NIBR (2013)

*245 Chrysosplenium epigealum J. W. Han \& S. H. Kang 기는괭이눈, GW, Han and Kang (2012)

246 Chrysosplenium flaviflorum Ohwi 누른괭이눈, HB, KFS (2012); NIBR (2013)

247 Deutzia paniculata Nakai 꼬리말발도리, HN, GB; GN, KFS (2012); NIBR (2013)

248 Kirengeshoma koreana Nakai 나도승마, JN; GN, KFS (2012); NIBR (2013)

249 Micranthes octopetala (Nakai) Y. I. Kim \& Y. D. Kim 구실바위취, HB; HN; GG; GW; CB; JB, KFS (2012); NIBR (2013);

Kim et al. (2015c)

250 Saxifraga furumii Nakai 범의귀, HB; HN; PB, KFS (2012); NIBR (2013)

\section{Scrophulariaceae 현삼과}

251 Euphrasia coreana W. Becker 깔끔좁쌀풀, JJ (Hallasan), KFS (2012); NIBR (2013)

252 Euphrasia coreanalpina Nakai ex Kimura 애기좁쌀풀, HB; HN; PB, KFS (2012); NIBR (2013)

253 Euphrasia mucronulata Nakai ex Kimura 산좁쌀풀, HN, KFS (2012); NIBR (2013)

254 Euphrasia retrotricha Nakai ex T. Yamaz. 털좁쌀풀, HN, KFS (2012); NIBR (2013)

*255 Melampyrum koreanum K.-J. Kim \& S.-M. Yun 긴꽃며느리밥풀, GN (Somaemuldo), Kim and Yun (2012)

"256 Melampyrum setaceum (Maxim. ex Palib.) Nakai var. nakaianum (Tuyama) T. Yamaz. 새며느리밥풀, HB; PN; GW; GB, Yamazaki (1954)

257 Paulownia coreana Uyeki 오동나무, nearly all provinces (mainly planted); wild habitat unknown, KFS (2012); NIBR (2013) 258 Pedicularis hallaisanensis Hurus. 한라송이풀, JJ (Hallasan), KFS (2012); NIBR (2013)

259 Pedicularis ishidoyana Koidz. \& Ohwi 애기송이풀, GG; GW; GB; GN, KFS (2012); NIBR (2013)

260 Pedicularis lunaris Nakai 칼송이풀, HB; HN, KFS (2012); NIBR (2013)

261 Pedicularis nigrescens Nakai 바위송이풀, HB; HN, KFS (2012); NIBR (2013)

262 Pedicularis resupinata L. var. umbrosa Kom. ex Nakai 그늘송이풀, HB; HN; GW; GB, KFS (2012); NIBR (2013)

263 Scrophularia cephalantha Nakai 몽울토현삼, GW; GB; GN, NIBR (2013)

264 Scrophularia kakudensis Franch. var. microphylla Nakai 좀현삼, JJ, NIBR (2013)

*265 Scrophularia koraiensis Nakai 토현삼, GG; GW; CB; GB, Jang (2016)

266 Scrophularia takesimensis Nakai 섬현삼, GB (Ulleungdo), KFS (2012); NIBR (2013)

267 Veronica kiusiana Furumi var. diamantiaca (Nakai) T.Yamaz. 봉래꼬리풀, GW (Geumgangsan; Seoraksan), KFS (2012); NIBR (2013)

268 Veronica nakaiana Ohwi 섬꼬리풀, GB (Ulleungdo), KFS (2012); NIBR (2013)

*269 Veronica pusanensis Y. Lee 부산꼬리풀, GN (Busan), Lee (2004) 
270 Veronica pyrethrina Nakai 가새잎꼬리풀, GB, KFS (2012); NIBR (2013)

\section{Theaceae 차나무과}

271 Stewartia koreana Nakai ex Rehder 노각나무, PN; CB; GB; JN; GN, KFS (2012); NIBR (2013)

\section{Thymelaeaceae 팥꽃나무과}

*272 Daphne jejudoensis M. Kim 제주백서향, JJ (Seonheul), Lee et al. (2013b)

\section{Tiliaceae 피나무과}

273 Corchoropsis intermedia Nakai 암까치깨, PB, KFS (2012); NIBR (2013)

274 Tilia insularis Nakai 섬피나무, GB (Ulleungdo), KFS (2012); NIBR (2013)

*275 Tilia koreana Nakai 연밥피나무, GW, Boo and Park (2016)

276 Tilia semicostata Nakai 개염주나무, PN, KFS (2012); NIBR (2013)

\section{Ulmaceae 느릅나무과}

277 Celtis choseniana Nakai 검팽나무, HW; GW; GB; JN, KFS (2012); NIBR (2013)

278 Celtis edulis Nakai 노랑팽나무, HB; GW, KFS (2012); NIBR (2013)

279 Celtis taihyunchungii M. Kim 장수팽나무, HW (Jangsusan), KFS (2012); NIBR (2013); Kim (2017b)

280 Ulmus ×mesocarpa M. Kim 중느릅나무, GW, KFS (2012); NIBR (2013); Kim (2017b)

\section{Urticaceae 쐐기풀과}

281 Boehmeria taquetii Nakai 섬거북꼬리, JJ, KFS (2012); NIBR (2013)

282 Pilea oligantha Nakai 강계큰물통이, PB; HN; GW (Jeokgeunsan), KFS (2012); NIBR (2013)

283 Pilea taquetii Nakai 제주큰물통이, GN; JJ, KFS (2012); NIBR (2013)

284 Urtica laetevirens Maxim. var. robusta F. Maek. 섬쐐기풀, GB (Ulleungdo); JN; JJ, KFS (2012); NIBR (2013)

\section{Valerianaceae 마타리과}

285 Valeriana dageletiana Nakai ex F. Maek. 넓은잎쥐오줌풀, GB (Ulleungdo), KFS (2012); NIBR (2013)

286 Patrinia saniculifolia Hemsl. 금마타리, HB; HN; PB; PN; HW; GW; GG; CB; GB; GN; JB, KFS (2012)

\section{Violaceae 제비꽃과}

287 Viola kapsanensis Nakai 갑산제비꽃, HN; GG (Gapyeong), KFS (2012); NIBR (2013)

288 Viola seoulensis Nakai 서울제비꽃, all provinces, KFS (2012); NIBR (2013)

*289 Viola ulleungdoensis M. Kim \& J. Lee 울릉제비꽃, GB (Ulleungdo), Lee et al. (2012a)

290 Viola woosanensis Y. Lee \& J. Kim 우산제비꽃, GB (Ulleungdo), KFS (2012)

\section{Zosteraceae 거머리말과}

291 Zostera geojeensis H. C. Shin, H. K. Choi \& Y. S. Oh 좀마디거머리말, CN (Mongsanpo); GN (Daedapo), KFS (2012); NIBR (2013)

\section{MONOCOTYLEDONEAE 단자엽식물강}

Amaryllidaceae 수선화과

292 Lycoris chejuensis K. Tae \& S. Ko 제주상사화, JJ, KFS (2012); NIBR (2013)

293 Lycoris chinensis Traub var. sinuolata K. Tae \& S. Ko ex K. Tae \& S. Ko 진노랑상사화, JB; JN, KFS (2012); NIBR (2013)

294 Lycoris flavescens M. Kim \& S. Lee 붉노랑상사화, GG; CN; JB; JN; JJ, KFS (2012); NIBR (2013)

295 Lycoris sanguinea Maxim. var. koreana (Nakai) T. Koyama 백양꽃, JB; JN; GN, KFS (2012)

296 Lycoris uydoensis M. Kim 위도상사화, JB (Wido), KFS (2012); NIBR (2013)

\section{Araceae 천남성과}

297 Arisaema takesimense Nakai 섬남성, GB (Ulleungdo), KFS (2012); NIBR (2013)

298 Arisaema thunbergii Blume subsp. geomundoense S.C. Ko 거문천남성, JN (Geomundo); JJ (Hallasan), KFS (2012); NIBR (2013)

\section{Commelinaceae 닭의장풀과}

299 Commelina minor Y. Lee \& Y.C. Oh 애기닭의장풀, GG (Yangpyeong), NIBR (2013)

\section{Cyperaceae 사초과}

300 Carex erythrobasis H. Lév. \& Vaniot 한라사초, all provinces, KFS (2012); NIBR (2013)

301 Carex humbertiana Ohwi 큰뚝사초, HB, KFS (2012); NIBR (2013)

302 Carex ochrochlamys Ohwi 애기이삭사초, HB; HN, KFS (2012); NIBR (2013) 
303 Carex okamotoi Ohwi 지리대사초, central to southern provinces, KFS (2012); NIBR (2013)

304 Carex phaeothrix Ohwi 조이삭사초, HB, KFS (2012)

305 Carex pseudochinensis H. Lév. \& Vaniot 햇사초, PN; GG; GN, KFS (2012); NIBR (2013)

306 Carex sabynensis Less. ex Kunth var. leiosperma Ohwi 지리실청사초, GN; JB; JN, KFS (2012)

*307 Carex splendentissima U. Kang \& J. M. Chung 반들대사초, GW (Jeongseon; Pyeongchang); CB (Jecheon), Kang et al. (2012)

308 Carex subumbellata Meinsh. var. koreana Ohwi 구름사초, HN, KFS (2012); NIBR (2013)

*309 Fimbristylis drizae J. Kim \& M. Kim 물하늘지기, JB (Jeongeup), Kim and Kim (2015a)

*310 Fimbristylis jindoensis J. Kim \& M. Kim 진도하늘지기, JN (Jindo), Kim and Kim (2015b)

*311 Neoscirpus dioicus Y. Lee \& Y. C. Oh 동강고랭이, GW (Jeongseon), Lee and Oh (2006)

312 Scleria mutoensis Nakai 무등풀, JN (habitat unclear), KFS (2012); NIBR (2013)

Dioscoreaceae 마과

*313 Dioscorea coreana (Prain \& Burkill) R. Knuth 푸른마, all provinces, Kim et al. (2016a)

Eriocaulaceae 곡정초과

314 Eriocaulon glaberrimum Miyabe \& Satake var. platypetalum (Satake) Satake 주검정곡정초, JJ; KFS (2012); NIBR (2013)

315 Eriocaulon sphagnicolum Ohwi 애기곡정초, HB, KFS (2012); NIBR (2013)

*316 Eriocaulon tenuissimum Nakai 가는개수염, GW (Jangjeon), Nakai (1917); Oh and Hur (2002)

Iridaceae 붓꽃과

317 Iris koreana Nakai 노랑붓꽃, JB; JN, KFS (2012); NIBR (2013)

318 Iris odaesanensis Y. Lee 노랑무늬붓꽃, GW; CB; GB, NIBR (2013)

319 Iris rossii Baker var. latifolia J. K. Sim \& Y. S. Kim 넓은잎각시붓꽃, CN; JB; JN, KFS (2012); NIBR (2013)

Juncaceae 골풀과

320 Luzula odaesanensis Y. Lee \& Y. Chae ex M. Kim 오대산새밥, GW, KFS (2012); NIBR (2013); Kim (2017b)

\section{Liliaceae 백합과}

321 Allium koreanum H. J. Choi \& B. U. Oh 돌부추, JB; GB; GN, NIBR (2013)

322 Allium linearifolium H. J. Choi \& B. U. Oh 선부추, CB, NIBR (2013)

323 Allium minus (S. Yu, W. Lee \& S. Lee) H.J. Choi \& B.U. Oh 좀부추, probably extinct in wild; cultivated mainly in GW and GG, NIBR (2013)

324 Allium taquetii H. Lév. 한라부추, JJ (Hallasan), KFS (2012); NIBR (2013)

325 Allium thunbergii G. Don. var. deltoides (S. Yu, S. Lee \& W. Lee) H.J. Choi \& B.U. Oh 세모산부추, GN (Gayasan), Choi and Oh (2003); NIBR (2013)

326 Allium thunbergii G. Don var. teretifolium H. J. Choi \& B. U. Oh 둥근산부추, JB; JN, NIBR (2013)

327 Heloniopsis koreana Fuse, N. S. Lee \& M. N. Tamura 처녀치마, PN; HN; GG; GW; JN, KFS (2012)

328 Hemerocallis hakuunensis Nakai 백운산원추리, central to southern provinces, KFS (2012); NIBR (2013)

329 Hemerocallis hongdoensis M. G. Chung \& S. S. Kang 홍도원추리, JN (Hongdo; Gageodo; Heuksando), KFS (2012)

330 Hemerocallis taeanensis S. S. Kang \& M. G. Chung 태안원추리, CN (Taean), KFS (2012); NIBR (2013)

*331 Heloniopsis tubiflora Fuse, N. S. Lee \& M. N. Tamura 숙은처녀치마, GW; JB; JN; GN, Fuse et al. (2004)

*332 Hosta clausa Nakai var. geumgangensis M. Kim \& H. Jo 금강비비추, JB (Jinan), Jo and Kim (2016)

333 Hosta jonesii M. G. Chung 다도해비비추, GN; JN, KFS (2012); NIBR (2013)

334 Hosta minor (Baker) Nakai 좀비비추, central and southern provinces, KFS (2012); NIBR (2013)

335 Hosta venusta F. Maek. 한라비비추, JJ (Hallasan), KFS (2012); NIBR (2013)

336 Hosta yingeri S. B. Jones 흑산도비비추, JN (Heuksando), KFS (2012); NIBR (2013)

337 Lilium hansonii Leichtlin ex D. D. T. Moore 섬말나리, GB (Ulleungdo), KFS (2012); NIBR (2013)

338 Polygonatum grandicaule Y. S. Kim, B. U. Oh \& C.G. Jang 선둥굴레, CB (Gakhosan; Minjujisan), KFS (2012); NIBR (2013)

339 Polygonatum infundiflorum Y. S. Kim, B. U. Oh \& C. G. Jang 늦둥굴레, GG (Pungdo), KFS (2012); NIBR (2013)

340 Smilacina bicolor Nakai 자주솜대, HB; HN; GW; CB; JB, KFS (2012); NIBR (2013)

*341 Tofieldia yoshiiana Makino var. koreana (Ohwi) M. N. Tamura, Fuse \& N.S. Lee 꽃장포, GW (Wonsan), Tamura et al. (2013)

Orchidaceae 난초과

342 Goodyera ×tamnaensis N. S. Lee, K. S. Lee, S. H. Yeau \& C. S. Lee 탐라사철란, JJ (Seogwipo), KFS (2012) 
343 Habenaria chejuensis Y. Lee \& K. S. Lee 제주방울란, JJ (Daejeong), NIBR (2013)

344 Habenaria cruciformis Ohwi 개잠자리난초, GW; GG; GN, KFS (2012); NIBR (2013)

345 Liparis koreana (Nakai) Nakai 참나리난초, HB; HN; PB; GW; GG; JB, KFS (2012); NIBR (2013)

346 Liparis pterosepala N. S. Lee, C. S. Lee \& K. S. Lee 날개옥잠화, JJ, KFS (2012)

347 Liparis yongnoana N. S. Lee, C. S. Lee \& K. S. Lee 계우옥잠화, JJ, KFS (2012)

348 Oreorchis coreana Finet 두잎감자난초, JJ, KFS (2012); NIBR (2013)

Poaceae 벼과

349 Arundinaria munsuensis Y. Lee 문수조릿대, JN (Jirisan), KFS (2012); NIBR (2013)

350 Calamagrostis paishanensis Nakai 백산새풀, northern provinces, KFS (2012); NIBR (2013)

351 Calamagrostis subacrochaeta Nakai 낭림새풀, PB (Nangnimsan), KFS (2012); NIBR (2013)

352 Festuca ovina L. var. chosenica Ohwi 수염김의털, HB; GN (Jirisan), KFS (2012); NIBR (2013)

353 Festuca ovina L. var. koreanoalpina Ohwi 두메김의털, HB; HN; PB; GW; GN; JJ, KFS (2012); NIBR (2013)

354 Miscanthus changii Y. Lee 장억새, GW; GG, KFS (2012); NIBR (2013)

355 Poa deschampsioides Ohwi 좀새포아풀, HB; HN, KFS (2012); NIBR (2013)

356 Poa kumgangsani Ohwi 금강포아풀, GE (Geumgansan), KFS (2012); NIBR (2013)

357 Poa takeshimana Honda 섬포아풀, GB (Ulleungdo), KFS (2012); NIBR (2013)

358 Poa ullungdoensis I. C. Chung 울릉포아풀, GB (Ulleungdo), KFS (2012); NIBR (2013)

359 Sasa coreana Nakai 고려조릿대, HB, KFS (2012); NIBR (2013)

360 Sasa quelpaertensis Nakai 제주조릿대, JJ, KFS (2012); NIBR (2013) 


\section{Appendix 2. List of excluded taxa from KFS (2012) and NIBR (2013).}

The information is listed as follow; scientific and vernacular names, reference and note.

\section{PTERIOPHYTA 양치식물문}

Apleniaceae 꼬리고사리과

1 Asplenium sarelii Hook. var. anogrammoides (Christ) Tagawa 바위좀고사리, KFS (2012), synonym of A. anogrammoides Christ (Lin and Viane, 2013)

\section{Athyriaceae 개고사리과}

2 Athyrium nakaii Tagawa 강원고사리, KFS (2012), synonym of Dryopteris goeringiana (Kuntze) Koidzumi (Kim et al., 2015a)

\section{Dryopteridaceae 관중과}

3 Dryopteris austriaca (Jacq.) Woyn. ex Schinz \& Thell. var. subopposita H. Ito 금강고사리, KFS (2012), unable to check validly published description or diagnosis

Thelypteridaceae 처녀고사리과

4 Phegopteris koreana B. Y. Sun \& C. H. Kim 큰설설고사리, KFS (2012), distributed in Japan (Kim et al., 2015b)

Woodsiaceae 우드풀과

5 Woodsia pseudoilvensis Tagawa 메가물고사리, KFS (2012), synonym of W. subcordata Turcz. (Kim and Sun, 2015)

6 Woodsia saitoana Tagawa 좁쌀우드풀, KFS (2012), synonym of W. subcordata Turcz. (Kim and Sun, 2015)

ANGIOSPERMAE 피자식물문

DICOTYLEDONEAE 쌍자엽식물강

Actinidiaceae 다래나무과

7 Actinidia arguta (Siebold \& Zucc.) Planch. ex Miq. var. rufinervis Nakai 녹다래나무, NIBR (2013), synonym of $A$. arguta (Siebold \& Zucc.) Planch. ex Miq. (Kim and Oh, 2013)

\section{Apiaceae 산형과}

8 Angelica cartilaginomarginata (Makino ex Y. Yabe) Nakai var. distans (Nakai) Kitag. 흰바디나물, NIBR (2013), synonym of A. cartilaginomarginata (Makino ex Y. Yabe) Nakai (Yoon, 1994)

9 Angelica polymorpha Maxim. var. fallax (Boiss.) Kitag. 개강활, NIBR (2013), synonym of A. polymorpha Maxim. (Yoon, 1994)

10 Coelopleurum nakaianum (Kitag.) Kitag. 부전바디, NIBR (2013), distributed in China (Lee, 1996)

11 Tilingia nakaiana Kitag. 속리참나물, KFS (2012); NIBR (2013), synonym of T. tsusimensis (Y. Yabe) Kitag. (Kim et al., 2007)

\section{Aristolochiaceae 쥐방울덩굴과}

12 Asarum misandrum B. U. Oh \& J. G. Kim 각시족도리풀, KFS (2012); NIBR (2013), distributed in Japan (Oh, 2008)

13 Asarum yeonbyeonense M. Kim \& S. So 연변족도리풀, KFS (2012), distributed in China (So et al, 2010)

\section{Asteraceae 국화과}

14 Achillea ptarmica L. var. acuminata (Ledeb.) Heimerl 큰톱풀, KFS (2012); NIBR (2013), synonym of A. acuminata (Ledeb.) Sch.-Bip. (Afanasiev and Botschantzev, 1961)

15 Artemisia japonica Thunb. var. angustissima (Nakai) Kitam. 실제비쑥, NIBR (2013), synonym of A. angustissima Naka (Park, 2012)

16 Aster chezuensis (Kitam.) Nakai 제주국화, KFS (2012); NIBR (2013), synonym of A. hispidus Thunb. (Kim, 2017a)

17 Cirsium vlassovianum Fisch. ex DC. var. album Nakai 민흰잎엉겅퀴, NIBR (2013), possible synonym of C. vlassovianum Fisch. ex DC. (Im, 1999)

18 Hieracium coreanum Nakai 껄껄이풀, KFS (2012), distributed in China [=Crepis coreana (Nakai) H.S. Pak] (Zhu and Kilian, 2011)

19 Leontopodium seorakensis Y. S. Lim, J. O. Hyun, Y. D. Kim \& H. Shin 설악솜다리, NIBR (2013), synonym of L. leiolepis Nakai (Lee at al., 2016)

20 Parasenecio koraiensis (Nakai) B. U. Oh 참나래박쥐, KFS (2012), invalidly published name [Cacalia koraiensis Nakai (1952) is nom. nud.]

21 Saussurea maximowiczii Herder var. triceps (H. Lév. \& Vaniot) Kitam. 한라분취, KFS (2012); NIBR (2013), synonym of S. maximowiczii Herder (Hassler, 2017) 
22 Saussurea triangulata Trautv. \& C. A. Mey. var pinnatifida (Nakai) Kitam. 깃덤불취, NIBR (2013), synonym of S. manshurica Kom. (Hassler, 2017)

23 Senecio birubonensis Kitam. 금강솜방망이, KFS (2012); NIBR (2013), synonym of Tephroseris phaeantha (Nakai) C. Jeffrey $\&$ Y.L. Chen (Jeffrey and Chen, 1984)

24 Senecio koreanus Kom. 국화방망이, KFS (2012), distributed in China [=Tephroseris koreana (Kom.) B. Nord. \& Pelser] (Nordenstam and Pelser, 2011)

\section{Balsaminaceae 봉선화과}

25 Impatiens violascens B. U. Oh and Y. Y. Kim 꼬마물봉선, GB (Bohyeonsan), KFS (2012), later homonym of I. violacea M. Kumar \& Sequiera (2001) (Park et al., 2013a)

\section{Betulaceae 자작나무과}

26 Betula ermanii Cham. var. saitoana (Nakai) Hatusima 좀고채목, KFS (2012), synonym of B. ermanii Cham. (Govaerts and Bopp, 2017)

\section{Brassicaceae 십자화과}

27 Arabis ligulifolia Nakai 주걱장대, NIBR (2013), synonym of A. pendula L. (Iwatsuki et al., 2006)

28 Arabis serrata Franch. \& Sav. var. hallaisanensis (Nakai) Ohwi 바위장대, NIBR (2013), possible synonym of $A$. serrata Franch. \& Sav. (Oh, 2007a)

29 Cardamine glechomifolia H. Lév. 벌깨냉이, KFS (2012); NIBR (2013), distributed in China and Japan (= C. anhuiensis D.C. Zhang \& C.Z. Shao in China; = C. arakiana Koidz. in Japan) (Kim, 2015c)

30 Cardamine koreana (Nakai) Nakai 참고추냉이, NIBR (2013), synonym of C. leucantha (Tausch) O.E. Schulz (Song and Park, 2012) 31 Cardamine pseudowasabi H. Shin \& Y. D. Kim 고추냉이, KFS (2012), possible synonym of Eutrema japonicum (Miq.) Koidz. (Y. Y. Kim, pers, comm.)

\section{Campanulaceae 초롱꽃과}

32 Adenophora obovata Kitam. 관악잔대, KFS (2012); NIBR (2013), synonym of A. polyantha Nakai (Yoo, 1995)

33 Adenophora pulchra Kitam. 금강잔대, KFS (2012); NIBR (2013), synonym of A. triphylla (Thunb.) A. DC. (Govaerts, 1995) Caprifoliaceae 인동과

34 Lonicera tatarinowii Maxim. var. leptantha (Rehder) Nakai 흰괴불나무, KFS (2012); NIBR (2013), synonym of L. tatarinowii Maxim. (Lee, 1996)

35 Zabelia mosanensis Hisauti \& H. Hara 댕강나무, NIBR (2013), synonym of Z. biflora (Turcz.) Makino (Kim, 1998)

\section{Carylphyllaceae 석죽과}

36 Pseudostellaria bulbosa (Nakai) Ohwi 덩이뿌리개별꽃, KFS (2012), synonym of P. heterophylla (Miq.) Pax (Hassler, 2017); possible synonym of $P$. davidii (Franch.) Pax (K. Choi, pers. comm.)

\section{Celastraceae 노박덩굴과}

37 Buxus koreana (Nakai ex Rehder) T. H. Chung, P. S. Toh, D. B. Lee \& F. J. Lee. 회양목, KFS (2012), distributed in China (Kim, 2015a)

38 Euonymus alatus (Thunb.) Siebold var. uncinatus Nakai 삼방회잎나무, KFS (2012), synonym of E. alatus (Thunb.) Siebold f. apterus (Regel) Rehder (Kim, 1993)

\section{Crassulaceae 돌나물과}

39 Orostachys filifera (Nakai) Nakai 애기바위솔, NIBR (2013), synonym of O. spinosa (L.) C. A. Meyer ex A. Berger (Ohba, 2003a) 40 Rhodiola angusta Nakai 좁은잎돌꽃, KFS (2012), distributed in China (= R. ramosa Nakai) (Ohba, 2003b)

41 Sedum aizoon L. var. ramosum Uyeki \& Sakata 가지기린초, NIBR (2013), synonym of S. aizoon L. (Hart and Bleij, 2003)

42 Sedum zokuriense Nakai 속리기린초, KFS (2012); NIBR (2013), possible synonym of S. kamtschaticum Fisch. (Lee et al., 2003)

Ericaceae 진달래과

43 Rhododendron saisiuense Nakai 한라산참꽃, KFS (2012), synonym of R. kiusianum Makino (Yamazaki, 1996)

44 Vaccinium hirtum Thunb. var. koreanum (Nakai) Kitam. 산앵도나무, KFS (2012); NIBR (2013), distributed in China (Fang and Stevens, 2005)

Euphorbiaceae 대극과

45 Euphorbia octoradiata H. Lév. \& Vaniot 제주대극, NIBR (2013), synonym of E. esula L. (Park, 2015)

46 Euphorbia pekinensis Rupr. var. subulatifolius (Hurus.) T. B. Lee 목포대극, KFS (2012); NIBR (2013), synonym of E. lasiocaula Boiss. (Park, 2015) 


\section{Fabaceae 콩과}

47 Astragalus koraiensis Y. Lee 정선황기, NIBR (2013), synonym of A. sikokianus Nakai (Choi et al., 2015)

48 Lespedeza bicolor Turcz. var. sericea Nakai 털싸리, NIBR (2013), synonym of L. bicolor Turcz. (Akiyama, 1988)

49 Lespedeza maximowiczii C. K. Schneid. var. tomentella (Nakai) Nakai 털조록싸리, NIBR (2013), synonym of L. maximowiczii C. K. Schneid. (Akiyama, 1988)

50 Lespedeza pilosa (Thunb.) Siebold \& Zucc var. pedunculata T.B. Lee 긴괭이싸리, NIBR (2013), possible synonym of $L$. pilosa (Thunb.) Siebold \& Zucc. (B.H. Choi, pers. comm.)

51 Lespedeza robusta Nakai 고양싸리, NIBR (2013), synonym of L. formosa (Vogel) Koehne (Hatusima, 1967)

52 Oxytropis strobilaca Bunge 시루산돔부, KFS (2012), distributed in Russia (Kholina et al., 2016)

53 Vicia angustipinnata Nakai 가는갈퀴나물, NIBR (2013), synonym of V. hirticalycina Nakai (Choi and Kwon, 2001)

54 Vicia linearifolia Y. Lee 계방나비나물, KFS (2012); NIBR (2013), later homonym of V. linearifolia Hook. \& Arn. (1830) (Park et al., 2013a)

\section{Fagaceae 참나무과}

55 Quercus dentata Thunb. var. fallax Nakai 청떡갈나무, NIBR (2013), synonym of Q. dentata Thunb. (Govaerts, 2004)

56 Quercus gluca Thunb. var. nudata Blume 흰민종가시, KFS (2012), possible synonym of Q. glauca Thunb. (Lee, 2012)

57 Quercus stenophylla (Blume) Makino var. latifolia Nakai 넓은잎참가시나무, NIBR (2013), possible synonym of $Q$. salicina Blume f. latifolia (Nakai) W. Lee (Lee, 1996)

\section{Geraniaceae 쥐손이풀과}

58 Geranium eriostemon Fisch. ex DC. var. glabrescens Nakai ex H. Hara 부전쥐손이, NIBR (2013), synonym of G. platyanthum Duthie (Xu and Aedo, 2008)

59 Geranium koraiense Nakai 참이질풀, KFS (2012), later homonym of G. koreanum Kom. (1901)

60 Geranium koreanum Kom. 둥근이질풀, NIBR (2013), distributed in China (Xu and Aedo, 2008)

Juglandaceae 가래나무과

61 Platycarya strobilacea Siebold et Zucc. var. coreana Miq. 털굴피나무, NIBR (2013), synonym of P. strobilacea Siebld et Zucc. f. coreana (Miq.) W. T. Lee (Lee, 1996)

\section{Lamiaceae 꿀풀과}

62 Mentha arvensis L. var. barbata (Nakai) W. Lee 털박하, KFS (2012); NIBR (2013), synonym of M. canadensis L. (Tucker and Naczi, 2007)

63 Scutellaria indica L. var. alba S. Kim \& S. Lee 비바리골무꽃, KFS (2012); NIBR (2013), synonym of S. indica L. (Govaerts, 2003)

\section{Loganiaceae 마전과}

64 Gardneria insularis Nakai 영주치자, KFS (2012), synonym of G. nutans Siebold \& Zucc. (Leenhouts, 1962)

\section{Oleaceae 물푸레나무과}

65 Forsythia saxatilis (Nakai) Nakai 산개나리, KFS (2012); NIBR (2013), synonym of F. ovata Nakai (Chung et al., 2013; De Juana Clavero, 2016)

66 Fraxinus quadrijuga Nakai 백운쇠물푸레, NIBR (2013), possible synonym of F. sieboldiana Blume (Chang et al., 2011)

67 Ligustrum acutissimum Koehne 산동쥐똥나무, KFS (2012), synonym L. leucanthum (S. Moore) P.S. Green (Green, 1995; De Juana, 2009)

68 Syringa fauriei H. Lév. 버들개회나무, KFS (2012), synonym of S. reticulata (Blume) H. Hara subsp. amurensis (Rupr.) P.S. Green \& M.C. Chang (Chen, 2008)

69 Syringa patula (Palib.) Nakai var. venosa (Nakai) M. Kim 섬개회나무, KFS (2012); NIBR (2013), synonym of S. pubescens Turcz. subsp. patula (Palib.) M. C. Chang \& X. L. Chen (Chen et al., 2009)

70 Syringa wolfii C. K. Schneid. var. hirsuta (C. K. Schneid) Rehder 털꽃개회나무, NIBR (2013), synonym of S. villosa subsp. wolfii (C. K. Schneid.) Jin Y. Chen \& D.Y. Hong (Chen, 2008)

\section{Ranunculaceae 미나리아재비과}

71 Clematis flabellata Nakai 요강나물, KFS (2012); NIBR (2013), synonym of C. fusca Turcz. (Hassler, 2017)

72 Clematis mandshurica Rupr. var. koreana (Nakai) Nakai ex Mori 큰위령선, NIBR (2013), possible synonym of C. terniflora DC. var. mandshurica (Rupr.) Ohwi (NIBR, 2013) 
73 Thalictrum rochebrunnianum Franch. \& Sav. var. grandisepalum (H. Lév.) Nakai 금꿩의다리, NIBR (2013), synonym of $T$. rochebrunnianum Franch. \& Sav. (Iwatsuki et al., 2006)

74 Thalictrum uchiyamai Nakai 자주꿩의다리, NIBR (2013), distributed in Japan (Iwatsuki et al., 2006)

\section{Rosaceae 장미과}

75 Potentilla dickinsii Franch. et Sav. var. breviseta Nakai 참양지꽃, NIBR (2013), synonym of P. dickinsii Franch. et Sav. (Iwatsuki et al., 2001)

76 Potentilla dickinsii Franch. et Sav. var. glabrata Nakai 섬양지꽃, KFS (2012); NIBR (2013), synonym of P. dickinsii Franch. Et Sav. (Iwatsuki et al., 2001)

77 Pourthiaea villosa (Thunb.) Decne. var. brunnea (H. Lév.) Nakai 떡잎윤노리나무, KFS (2012); NIBR (2013), synonym of $P$. villosa (Thunb.) Decne. (Liu and Hong, 2016)

78 Rosa kokusanensis Nakai 흑산가시, KFS (2012); NIBR (2013), synonym of R. lucieae Franch. \& Rochebr. (Chang et al., 2011; Hassler, 2017)

79 Rosa maximowicziana Regel var. pilosa (Nakai) Nakai 털용가시, KFS (2012); NIBR (2013), synonym of R. maximowicziana Regel (Hassler, 2017)

80 Rubus parvifolius L. var. taquetii (H. Lév.) Lauener \& D.K. Ferguson 사슨딸기, NIBR (2013), synonym of R. parvifolius L. (Iwatsuki et al., 2001)

81 Rubus tozawae Nakai ex J.Y. Yang var. longisepalus J.Y. Yang 맥도딸기, KFS (2012), possible synonym of R. ribisoideus Matsum. (Yang et al., 2012)

82 Sanguisorba hakusanensis Makino var. coreana H. Hara 산오이풀, NIBR (2013), synonym of S. hakusanensis Makino (Lee et al., 2000)

83 Sorbus amurensis Koehne var. latifoliolata Nakai 넓은잎당마가목, NIBR (2013), synonym of S. commixta Hedl. (Park et al., 2013b)

84 Sorbus amurensis Koehne var. rufa Nakai 차빛당마가목, KFS (2012), synonym of S. commixta Hedl. (Park et al., 2013b)

85 Sorbus commixta Hedl. var. pilosa Nakai 잔털마가목, NIBR (2013), synonym of S. commixta Hedl. (Park et al., 2013b)

Rubiaceae 꼭두서니과

86 Galium boreale L. var. koreanum Nakai 털긴잎갈퀴, KFS (2012); NIBR (2013), synonym of G. boreale L. (Govaerts, 2003)

Rutaceae 운향과

87 Zanthoxylum coreanum Nakai 왕초피, KFS (2012), synonym of Z. simulans Hance (Murata, 1984)

\section{Salicaceae 버드나무과}

88 Populus glandulosa (Uyeki) Uyeki 수원사시나무, KFS (2012); NIBR (2013), later homonym of P. glandulosa Moench (1794)

89 Salix floderusii Nakai var. fuscescens Nakai 백산버들, KFS (2012); NIBR (2013), synonym of S. xerophila f. fuscescens (Nakai) W. G. Park (Park, 2007)

90 Salix pseudolasiogyne H. Lév 능수버들, KFS (2012), distributed in China (Fang et al., 1999)

91 Salix sericeocinerea Nakai 큰산버들, KFS (2012), distributed in Japan (Park, 2007)

\section{Saxifragaceae 범의귀과}

92 Astilbe rubra Hook.f. \& Thomson var. divaricata (Nakai) W. T. Lee 진퍼리노루오줌, KFS (2012); NIBR (2013), synonym of A. koreana (Kom.) Nakai (Han, 2016)

93 Chrysosplenium hallaisanense Nakai 제주괭이눈, NIBR (2013), synonym of C. barbatum Nakai (Kim, 2015b)

94 Mukdenia rossii (Oliv.) Koidz. var. multiloba (Nakai) Nakai 큰돌단풍, NIBR (2013), synonym of M. rossii (Oliv.) Koidz. (Lee, 1996) 95 Philadelphus koreanus Nakai 양덕고광나무, KFS (2012); NIBR (2013), synonym of P. tenuifolius Rupr. (Park et al., 2005)

96 Philadelphus scaber Nakai 섬고광나무, KFS (2012); NIBR (2013), synonym of P. tenuifolius Rupr. (Park et al., 2005)

97 Philadelphus seoulensis Y. H. Chung \& H. C. Shin 서울고광나무, KFS (2012); NIBR (2013), synonym of P. tenuifolius Rupr. (Park et al., 2005)

98 Saxifraga fortunei Hook. var. pilosissima Nakai 털바위떡풀, KFS (2012), synonym of S. foutunei Hook. var. aplina (Matsum. et Nakai) Nakai (Iwatsuki et al., 2001)

\section{Scrophulariaceae 현삼과}

99 Pedicularis mandshurica Maxim. var. coreana (Bonati) Hurus. 털만주송이풀, NIBR (2013), synonym of P. mandshurica Maxim. (Hassler, 2017) 
100 Pseudolysimachion kiusianum (Furumi) T. Yamaz. var. glabrifolium (Kitag.) T. Yamaz 큰산꼬리풀, KFS (2012), synonym of P. kiusianum (Furumi) T. Yamaz. (Hong et al., 1998)

101 Scrophularia buergeriana Miq. var. quelpartensis T. Yamaz. 제주현삼, KFS (2012); NIBR (2013), synonym of S. kakudensis Franch. var. microphylla Nakai (Jang, 2016)

\section{Solanaceae 가지과}

102 Scopolia lutescens Y. Lee 노랑미치광이풀, KFS (2012); NIBR (2013), synonym of S. japonica Maxim. (Jang et al., 2011)

Tiliaceae 피나무과

103 Tilia ovalis Nakai 웅기피나무, NIBR (2013), distributed in China (Tang et al., 2007)

Trapaceae 마름과

104 Trapa bicornis Osbeck 유전마름, KFS (2012), distributed in China (Na and Oh, 2015)

\section{Urticaceae 쐐기풀과}

105 Boehmeria hirtella Satake 털긴잎모시풀, NIBR (2013), synonym of B. sieboldiana Blume (Wilmot-Dear and Friis, 2013)

106 Boehmeria nakaiana Satake 제주긴잎모시풀, NIBR (2013), synonym of B. sieboldiana Blume (Wilmot-Dear and Friis, 2013)

107 Boehmeria quelpaertensis Satake 제주모시풀, KFS (2012); NIBR (2013), distributed in Japan (Yahara, 1983)

\section{Violaceae 제비꽃과}

108 Viola kapsanensis Nakai var. albiflora (Nakai) Nakai 흰갑산제비꽃, NIBR (2013), synonym of V. japonica Langsd. ex Ging (Hassler, 2017); possible synonym of $V$. kapsanensis Nakai (K.O. Yoo, pers. comm.)

109 Viola takesimana Nakai 섬제비꽃, KFS (2012); NIBR (2013), synonym of V. acuminata Ledeb. (Hassler, 2017); possible synonym of $V$. grypocera A. Gary (K.O. Yoo, pers. comm.)

\section{MONOCOTYLEDONEAE 단자엽식물강}

\section{Araceae 천남성과}

110 Pinellia koreana K. H. Tae \& J. H. Kim 지리반하, KFS (2012), synonym of P. ternata (Thunb.) Makino (Zhu et al., 2007) Cyperaceae 사초과

111 Carex aphanolepis Franch. \& Sav. var. mixta Nakai 잡골사초, KFS (2012), invalidly published name (nomen nudum)

112 Carex blepharicarpa Franch. var insularis Nakai 여우꼬리사초, NIBR (2013), synonym of C. blepharicarpa Franch. (Govaerts and Simpson, 2007)

113 Carex tenuiformis H. Lév. \& Vaniot var. neofilipes (Nakai) Ohwi ex Hatusima, 그늘실사초, KFS (2012), distributed in China, Japan and Russia (Oh, 2007c)

\section{Eriocaulaceae 곡정초과}

114 Eriocaulon latipetalum Y. C. Oh \& C. S. Heo 넓은꽃잎개수염, KFS (2012), invalidly published name (nomen nudum)

\section{Iridaceae 붓꽃과}

115 Iris sanguinea Donn ex Hornem. var. violacea Makino 진보라붓꽃, KFS (2012), possible synonym of I. sanguinea (J.-K. Sim, pers. comm.)

\section{Juncaceae 골풀과}

116 Luzula rufescens Fisch. ex E. Mey. 새밥, NIBR (2013), distributed in Russia, Mongolia, China, Japan and North America (Wu and Clemants, 2000)

\section{Liliaceae 백합과}

117 Allium deltoidefistulosum S. Yu, S. Lee \& W. Lee 세모부추, NIBR (2013), synonym of A. sacculiferum Maxim. (Choi and Oh, 2011)

118 Allium taquetii H. Lév. var. deltoides (S. Yu, S. Lee \& W. Lee) H. J. Choi \& B. U. Oh 한라세모부추, NIBR (2013), Scientific name error of $A$. thunbergii G. Don var. deltoides (S. O. Yu, S. T. Lee \& W. T. Lee) H.J. Choi \& B. U. Oh (Choi and Oh, 2003)

119 Lilium amabile Palib. 털중나리, NIBR (2013), distributed in China (Rong et al., 2011)

120 Lilium tenuifolium Fisch. var. chrysanthum Nakai 금나리, NIBR (2013), synonym of L. pumilum Delile (Govaerts, 2011)

121 Polygonatum odoratum (Mill.) Druce var. quelpaertense H. Hara 제주둥굴레, KFS (2012); NIBR (2013), synonym of $P$. odoratum (Mill.) Druce var. pluriflorum (Miq.) Ohwi (Jang, 1998)

122 Polygonatum stenanthum Nakai 좁은둥굴레, NIBR (2013), synonym of P. falcatum A. Gray (Tamura, 2008)

123 Veratrum oxysepalum Turcz. 푸른박새, NIBR (2013), distributed in China, Japan, and Russia (Kikuchi et al., 2010; Kim et al., 2014) 


\section{Orchidaceae 난초과}

124 Calanthe coreana Nakai 섬새우난초, KFS (2012); NIBR (2013), synonym of C. discolor Lindl (Lee, 2011)

125 Neottia hypocastanoptica Y. Lee 한라새둥지란, NIBR (2013), synonym of N. kiusiana T. Hashim. \& S. Hatus. (Lee, 2011)

\section{Poaceae 벼과}

126 Asperella coreana (Honda) Nevski 고려개보리, KFS (2012), distributed in China and Russia (Lee, 2007)

127 Calamagrostis hymenoglossa Ohwi 북선메뛰기피, KFS (2012); NIBR (2013), synonym of C. monticola V. Petrov ex Kom. (Tzvelev and Probatova, 2012)

128 Miscanthus oligostachyus Stapf subsp. intermedius (Honda) T. Koyama 억새아재비, KFS (2012), synonym of M. oligostachyus Stapf (Clayton et al., 2006)

129 Poa kanboensis Ohwi 관모포아풀, KFS (2012); NIBR (2013), distributed in China [= P. urssulensis Trin. var. kanboensis (Ohwi) Olonova \& G. Zhu] (Zhu et al., 2006)

130 Pseudosasa japonica (Steud.) Makino var. purpurascens Nakai 자주이대, NIBR (2013), synonym of P. japonica (Steud.) Makino (Ohrnberger, 1999)

131 Puccinellia coreensis Hack. ex Honda 갯겨이삭, KFS (2012); NIBR (2013), distributed in China (Liu et al., 2006)

132 Sasa chiisanensis (Nakai) Y. Lee 갓대, KFS (2012); NIBR (2013), synonym of S. borealis (Hack.) Makino \& Shibata (Ohrnberger, 1999) 